\title{
An overview of the mammals of the Gila region, New Mexico
}

\author{
Amanda K. Jones',2*, Schuyler W. Liphardt', Jonathan L. Dunnum', Travis W. Perry', Jason Malaneyª, and Joseph A. Cook' \\ ${ }^{1}$ Museum of Southwestern Biology and Biology Department, University of New Mexico, Albuquerque 87131. New Mexico, USA. \\ Email: akjone@sandia.gov(AKJ), liphardt@unm.edu (SWL), jldunnum@unm.edu (JLD), cookjose@unm.edu (JAC). \\ ${ }^{2}$ Sandia National Laboratories, Albuquerque. New Mexico, USA. \\ ${ }_{3}^{3}$ Department of Biology, Furman University, Greenville, SC 29613, U.S.A. Email: travis.perry@furman.edu (TWP). \\ ${ }^{4}$ New Mexico Museum of Natural History and Science, 1801 Mountain Rd, NW, 87104, Albuquerque. New Mexico, USA. Email: \\ jason.malaney@state.nm.us (JM). \\ *Corresponding author
}

A study of the mammals of the Gila region of New Mexico was conducted from 2012 through 2020, with 2,919 voucher specimens collected through fieldwork and collaborations with commercial trappers, in addition to data from camera traps, review of major holdings at 46 museums ( $n=12,505$ georeferenced specimens), and literature review. Specimens cover a 170-year span, dating back to 1850 and were unevenly distributed spatially and temporally across the Gila region. Most areas were very poorly represented and when summed across all mammal species, ranged from 0.02 to 3.7 specimens per $\mathrm{km}^{2}$. The survey documented 108 species (104 now extant) for the region. High species richness, greater than that reported for 38 states in the United States, is likely due to the juxtaposition of multiple biomes in the Gila, including the Sonoran, Chihuahuan, and Great Basin deserts, the Rocky Mountains and Sierra Madre Occidental, and nearby "sky islands" of the Southwest. Two species, Leptonycteris yerbabuenae and Zapus luteus, are documented for the first time from the study area. Expansions of the known range of these species, and Sciurus arizonensis are described from specimen and camera data. Preliminary phylogeographic studies of four species (Notiosorex crawfordi, Neotoma albigula, Perognathus flavus, and Thomomys bottae) using the mitochondrial cytochrome- $b$ gene reveal the dynamic biogeographic history of the region and reinforce how landscape complexity and climate change have jointly contributed to diversification and thus high mammalian diversity in the region.

Se condujo estudio de los mamíferos de la región Gila en Nuevo México desde 2012 hasta 2020, con 2,919 vouchers de especímenes recolectados a través de trabajo de campo y colaboraciones con cazadores comerciales, además de datos de trampas cámara, revisión de las principales colecciones en museos ( $n=12,505$ especímenes georeferenciadas) y revisión de literatura. Los especímenes cubren un lapso de 170 años, se remontan a 1850 y se distribuyeron de manera desigual en la región de Gila. La mayoría de las áreas estaban muy mal representadas, y sobre todo las especies oscilando entre 0.02 a 3.7 especímenes por km². En este estudio se documentaron 108 especies (104 existentes ahora) a la región. Alta riqueza de especies, más que la diversidad reportada para 38 estados en los Estados Unidos, se debe probablemente a la yuxtaposición de múltiples biomas en la región Gila, incluido los desiertos de Sonora, Chihuahua, y la Gran Cuenca, las Montañas Rocosas y la Sierra Madre Occidental, y las cercanas islas del cielo ("sky islands") del suroeste Estados Unidos. Dos especies, Leptonycteris yerbabuenae y Zapus luteus, se documentaron por primera vez en el área de estudio. Las expansiones de área de estas especies y Sciurus arizonensis se describen a partir de especímenes colectados y de cámaras trampa. Los estudios filogeográficos de cuatro especies (Notiosorex crawfordi, Neotoma albigula, Perognathus flavus y Thomomys bottae) utilizando el gen mitocondrial citocromo- $b$ revelan la historia biogeográfica dinámica de la región y refuerzan cómo la complejidad del paisaje y el cambio climático han contribuido a la alta diversidad de mamíferos en la región.

Keywords: biodiversity; conservation; distribution; Mammalia; Southwest; taxonomy.

C 2021 Asociación Mexicana de Mastozoología, www.mastozoologiamexicana.org

\section{Introduction}

Together with adjacent southeastern Arizona, the Gila Region of southwestern New Mexico (Figure 1) supports high biotic diversity, likely due to a dynamic geologic history, topographic complexity, considerable elevational relief, and the confluence of multiple, distinctive biomes. This diversity and an abundance of archaeological and paleontological sites have long generated interest in the fauna and flora of the region, including a series of mammalogists (e. g., Jones 1965; Hayward and Hunt 1972; Frey et al. 2008; Geluso and Geluso 2020). In a seminal paper on patterns of mammalian diversity across North America, Simpson (1945) noted that this region supported among the highest species richness north of the Mexican border (Figure 2). As a young forest ranger, Aldo Leopold spent his formative years in the region, gaining valuable insights in wildlife ecology and later proposing and pushing through Congress the creation of the renowned Gila Wilderness of New Mexico. This was the first federally designated wilderness in the United States (designated in June 1924) and, together with the adjoining Aldo Leopold Wilderness to the east (designated in 1980), these untrammeled wilderness areas encompass more than 309,000 ha and provide valuable habitat for wild mammals.

In recent decades, the Gila Region has been the focus of conservation efforts and controversy for several imperiled taxa (e. g., Hibbitts et al. 2009; National Academies of Sciences, Engineering and Medicine 2019; Propst et al. 2020): the Mexican spotted owl (Strix occidentalis lucida), Mexican gray wolf (Canis lupus baileyi), Chiricahua leopard frog (Lithobates chiricahuensis), Mexican garter snake (Thamnophis eques), and a series of threatened fishes (Gila trout, 
Oncorhynchus gilae, headwater chub, Gila nigra, loach minnow, Tiaroga cobitis, and spikedace, Meda fulgida). Despite this long history tied to conservation and the wealth of interest in the Gila, relatively few specimen-based biotic surveys (with the notable exception of fishes) have been conducted and no comprehensive review of the mammals of the region has been completed.

Herein we provide the first overview of the mammals of the Gila Region based on a synthesis of historical information (e. g., museum specimens), updated taxonomy and distributional data, the addition of 2,919 new specimens, and observational camera trap data for the region.

\section{Materials and Methods}

Study area. The Gila Project Area (hereafter the Gila), as defined in this study, encompasses $24,383 \mathrm{~km}^{2}$ in Catron, Grant, and Sierra counties of New Mexico (Figure 1). The western boundary is the border of New Mexico and Arizona, and the eastern border is the Rio Grande. The northern boundary is the southern end of the Plains of San Agustin, but extends north into the higher elevations of the Mangas, Escondido, and Gallo mountains and Jones Peak. The Gila is roughly bounded by the Deming Plains in the
South. The region includes both public (primarily the Gila National Forest with 1,335,462 ha, Bureau of Land Management with 1,042,386 ha, and New Mexico State Land Office with $676,864 \mathrm{ha}$ ) and private lands (e. g., small communities or ranches throughout the region).

Physiography and habitat. The Gila is located near the confluence of multiple major biomes, including three regional deserts: the northeastern Sonoran Desert, the northwestern Chihuahuan Desert, and the southern edge of the Great Basin Desert (Riddle and Hafner 2006). The Gila straddles the Continental Divide, which extends from the southern Rocky Mountains to the northern Sierra Madre Oriental. Regional desertification resulted from uplift of the Continental Divide during the Pliocene-Pleistocene ( 2 Ma; Wilson and Pitts 2010). As the eastern extension of the Mogollon Rim (Mogollon Plateau) of Arizona, the Gila is situated at the southern boundary of the Colorado Plateau and Basin and Range provinces (Julyan 2006), and is characterized by extensive topographic complexity that is compounded by relatively recent volcanism (Eocene, ca. $40 \mathrm{Ma}$ ). Regional basin and range block faulting and volcanism also resulted in "sky islands," isolated mountains surrounded by radically different lowland environments. Elevation

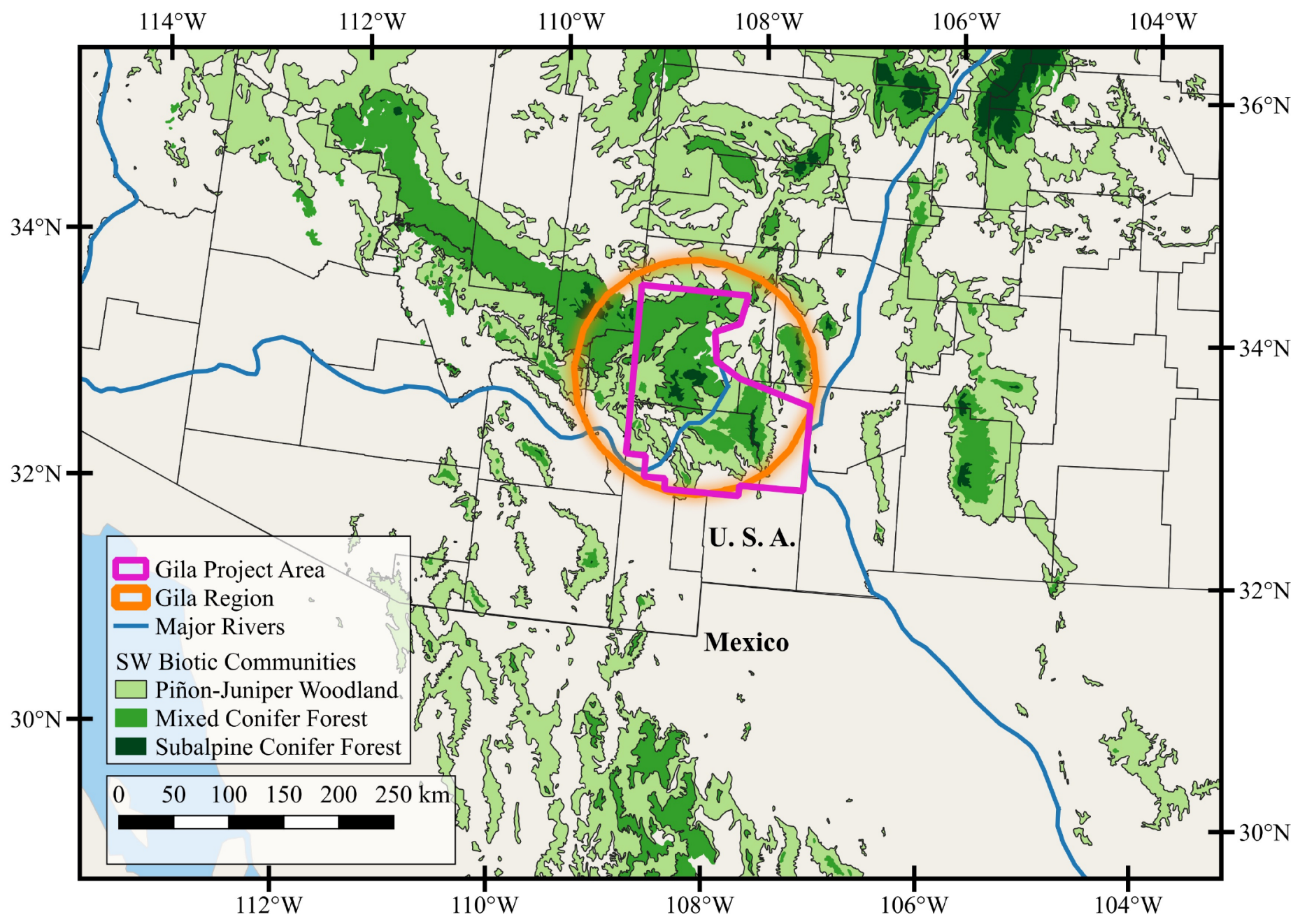

Figure 1. Location of the Gila Project Area and distribution of woodland and forest montane communities within the Sky Islands of the Southwest. 


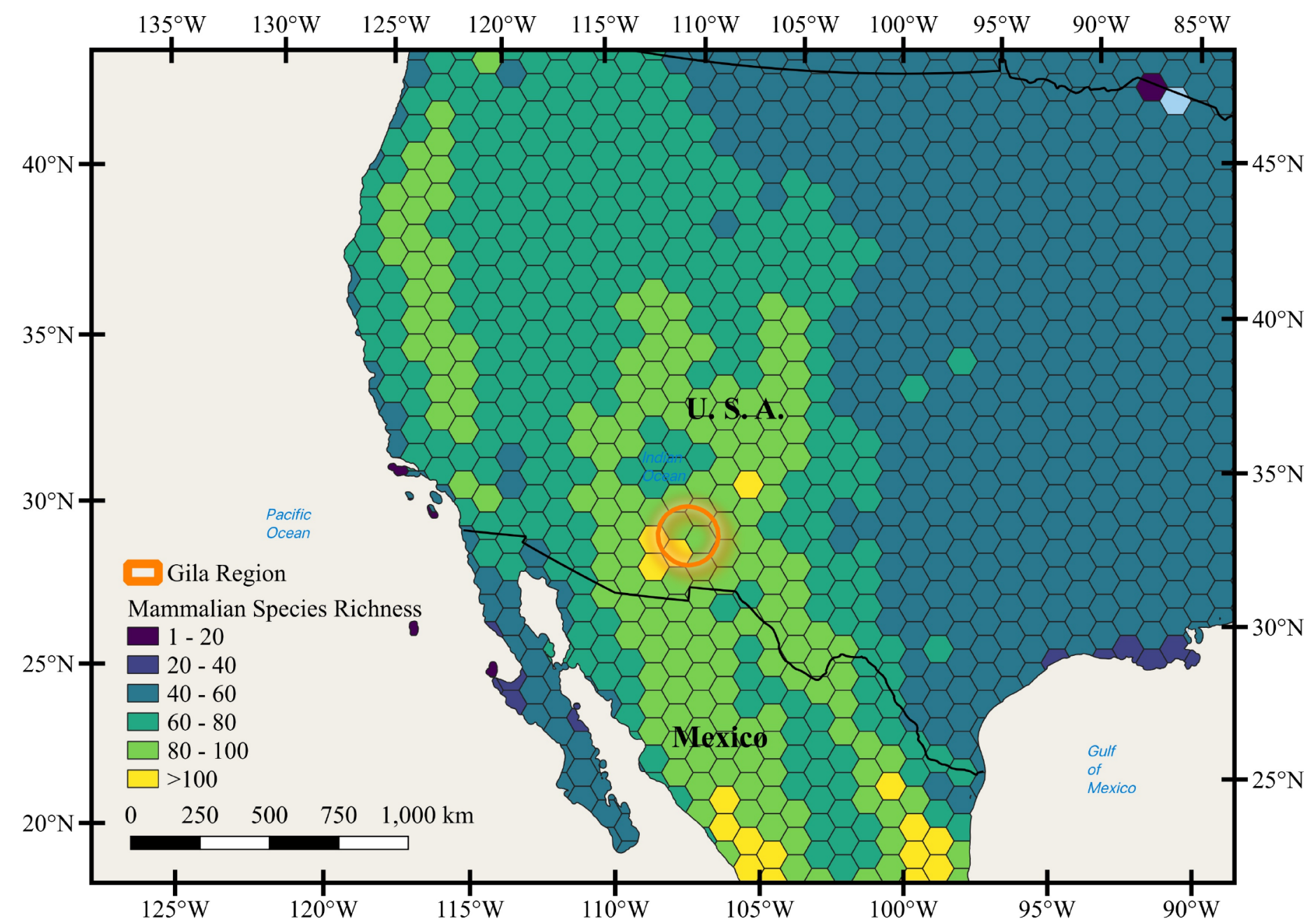

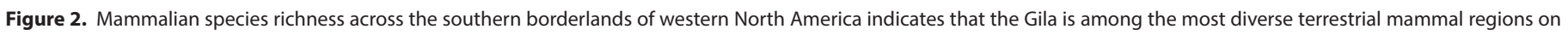
the continent. Each pixel represents an area of $100 \mathrm{~km}^{2}$ and the orange circle denotes the location of the Gila.

within the Gila ranges from 1,008 $\mathrm{m}$ where the San Francisco and Gila rivers meet to 3,322 $\mathrm{m}$ at Whitewater Baldy in the Mogollon Mountains. This substantial elevational relief and topographic complexity supports high habitat diversity and associated high mammalian diversity.

This generally arid region is transected by an array of river drainages and riparian systems. Most of the area is drained by the Gila River and numerous tributaries including the San Francisco River, whereas other creeks drain the area east of the Continental Divide into the Río Grande watershed. The Mimbres River drains the southcentral Gila into an endorheic basin on the Deming Plain (formerly Pleistocene Lake Animas). Vegetation in the Gila ranges from desert grassland at the lowest elevations, to desert scrubland, piñon-juniper woodland, ponderosa pine forest, and mixed coniferous forest and montane grassland at increasingly higher elevations (Dick-Peddie et al. 1993).

Collection survey. Four museum collections containing either the largest or most important historical series of mammal specimens for the Gila were visited, including the Museum of Southwestern Biology, University of New Mexico (MSB; $n=7,255$ ), Western New Mexico University
(WNMU; $n=2,474$ ), the National Museum of Natural History (USNM; $n=310$ ), and the American Museum of Natural History (AMNH; $n=262)$. These museums hold important historical specimens from the Gila, including species that were extirpated from the Gila, rarely occur in the Gila, or that may have expanded their distribution into the region. In order to identify all other records for the region, we performed a Global Biodiversity Information Facility (GBIF) search using the following parameters: mammal, from Catron, Grant, and Sierra Counties. In addition to the holdings from the four primary collections, specimen records from 42 other museums were downloaded (16,278 total; https://doi. org/10.15468/dl.vddbz5; accessed 20 November 2020). After culling county records which fell outside the delineated Gila region, a total of 12,505 georeferenced specimen records remained for further analyses (Figure 3 ). Of these, 3,773 specimen records were newly georeferenced using GeoLocate Web Application (https://www.geo-locate.org/).

Specimen collection. Field work (48 expeditions plus ancillary salvaged material from a total of 194 localities; Figure 4) was conducted from October 2012 to August 2020 throughout the region, with emphasis on the rela- 

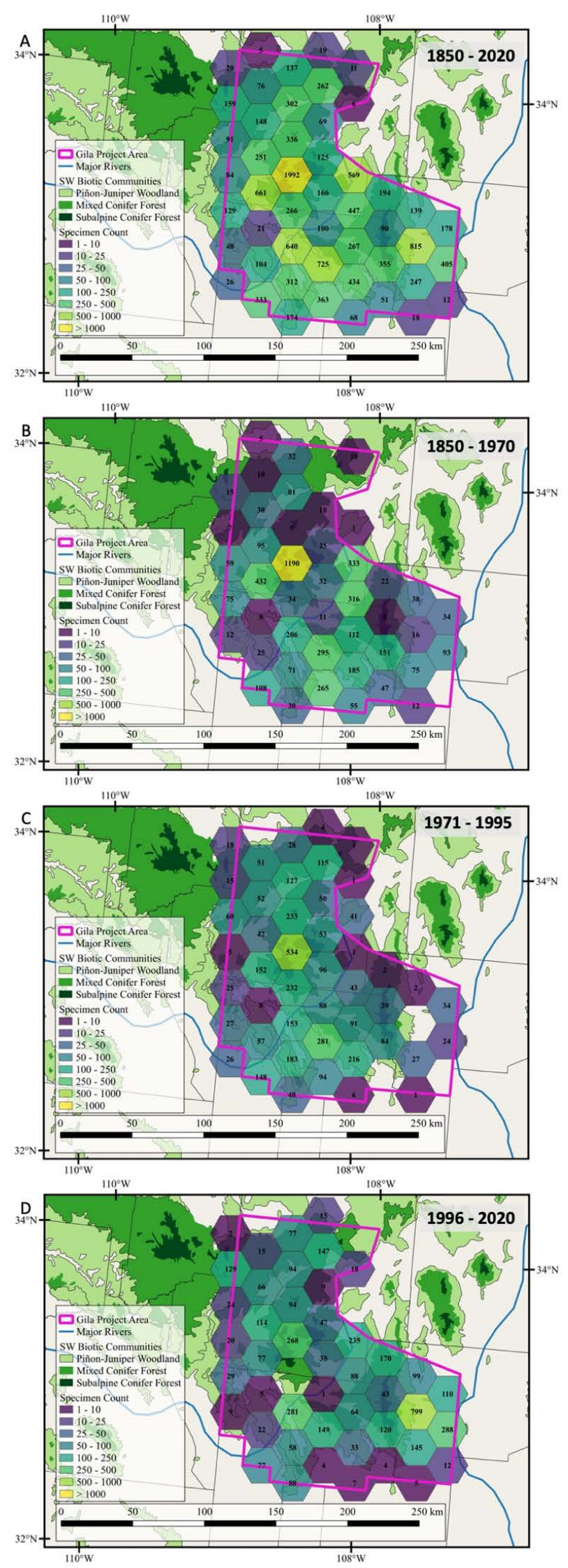

Figure 3. Temporal and spatial distribution of mammal specimens preserved from the Gila (1850-2020). These are compiled across all years (3a), but also broken into three time periods (3b, 1850-1970; 3c, 1971-1995; 3d, 1996-2020) to examine specimen density across time and especially in relation to the most recent period of accelerating environmental change. Hexagons $=541 \mathrm{~km}^{2}$. tively poorly documented eastern extent of the Gila in Sierra County, which includes the $636 \mathrm{~km}^{2}$ Ladder Ranch. This ranch has focused on privately-funded habitat and threatened species restoration efforts. Specimens were collected under a scientific collecting permit from the New Mexico Department of Game and Fish issued to Joseph Cook (NMDGF Cook \#3300), using standard trapping methods approved by the American Society of Mammalogists (Sikes et al. 2016) and the Institutional Animal Care and Use Committees at the University of New Mexico. Collecting efforts focused on producing holistic specimens (Cook et al. 2016; Schindel and Cook 2018) of rodents, bats, shrews, small carnivores, and their associated parasites from multiple sites representative of all major habitats in the Gila. Trapping was conducted primarily with Sherman $\odot$ live traps and museum special snap traps, augmented by Tomahawk $\odot$ live traps for small- to medium-sized mammals, Macabee $\odot$ traps for pocket gophers, and pitfall traps for shrews. Small mammal surveys were conducted by MSB field crews, some of which included UNM mammalogy field classes. Trap lines typically consisted of 50 live traps and 50 snap traps, with up to a total of 600 traps per night. Bats were collected with mist nets over streams, ponds, and stock tanks (Kunz and Parsons 2009), including sporadic netting during winter months, particularly the "buffer" months of November and March (Geluso 2007). GPS locations were recorded for all specimens along with standard voucher information. Specimens were preserved as either skin-plus-skeleton (Hafner et al. 1984) or fluid-preserved (95\% ethanol) along with multiple ultra frozen tissues (typically heart, lung, liver, kidney, spleen, and muscle) and ecto- and endoparasites (either preserved in $70 \% \mathrm{EtOH}$ or frozen in liquid nitrogen; Yates et al. 1996; Galbreath et al. 2019). All specimens were deposited in the collections of the Museum of Southwestern Biology (MSB) and available on the Arctos database (https://arctos.database.museum) along with historical records from MSB and WNMU.

Physical records of larger mammals were obtained through salvaged specimens archived at the MSB by the New Mexico Department of Game \& Fish, U. S. Department of Agriculture Wildlife Services, and local commercial fur trappers. Photographic data on medium and large mammals were collected from a grid of camera traps situated on the southern portion of the Ladder Ranch near Animas Creek (Figure 5) from April 2008 to 30 December 2019 for a total of 86,061 camera nights. The Ladder Ranch Headquarters is $14 \mathrm{~km}$ NNE of Hillsboro. Initial surveys (2008 to 2009 ) included 16 cameras (64 $\mathrm{km}^{2}$ coverage); an additional nine cameras ( $44 \mathrm{~km}^{2}$ coverage) were added in 2010 , for a total of 25 cameras and approximately $100 \mathrm{~km}^{2}$ of coverage. Additional records (e. g., annual harvests) and distributional information were obtained from the website of the New Mexico Department of Game and Fish (NMDGF; https://www.wildlife.state.nm.us/hunting/harvest-reporting-information). 


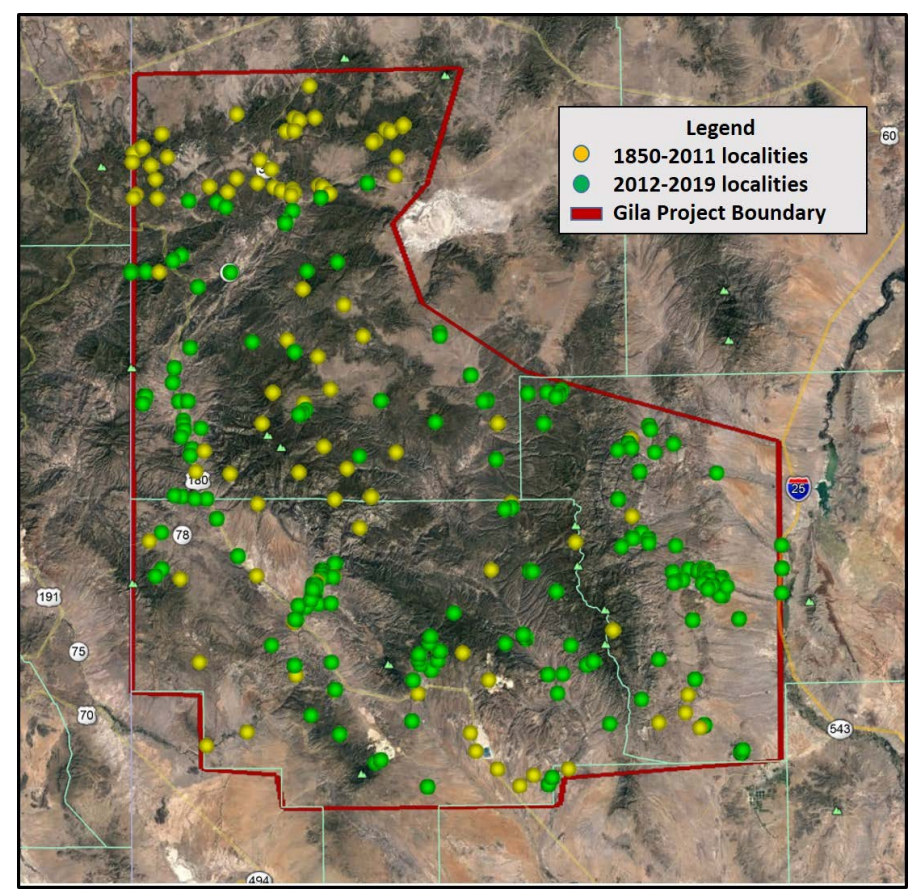

Figure 4. Sampling localities in the Gila. Yellow dots represent historical mammal collecting localities prior to our fieldwork (1851-2011) and green dots are collecting localities sampled during this study (2012-2020)

Over the last seven decades, a series of graduate studies that included Gila mammals were conducted, primarily at the University of New Mexico and New Mexico State University. We avoided unpublished reports on Gila mammals, particularly those that failed to produce data validated by specimens, due to the citation requirements of Therya. We acknowledge that there have been multiple bat, rodent, carnivore, or ungulate focused studies in the Gila that have produced non-peer reviewed reports and encourage their eventual publication. The one exception is that we include the specimen-based field studies of Bruce Hayward, who is now deceased. In particular, Hayward and Hunt (1972) summarizes a survey of remote sites in the Gila Wilderness (specimens deposited at WNMU) conducted in 1972.

Phylogeographic analyses. We compared sequences of the mitochondrial (mtDNA) cytochrome- $b$ gene (cytb) for four select species to begin to place specimens from the Gila into phylogeographic context and improve insights about the evolutionary history of these species. The species studied include representatives from the Gila, surrounding areas, and appropriate outgroups. For packrats, specimens include: Neotoma albigula $(\mathrm{n}=10$ individuals from three localities in the Gila), Arizona ( $n=7)$, and Chihuahua $(n=1), N$. leucodon $(n=3), N$. micropus $(n=2)$ including one from the Gila), N. stephensi ( $\mathrm{n}=4$ including one from the Gila), and N. mexicana $(n=4)$. Outgroups used to root this tree were Hodomys alleni and Neotoma cinerea. For pocket gophers, these include Thomomys bottae ( $\mathrm{n}=11$ individuals from five localities in the Gila), elsewhere in New Mexico $(n=7)$, Arizona $(n=4)$, and Texas $(n=4)$. Outgroups used to root this tree was Thomomys talpoides. For desert shrews, specimens include Notiosorex crawfordi ( $\mathrm{n}=5$ individuals
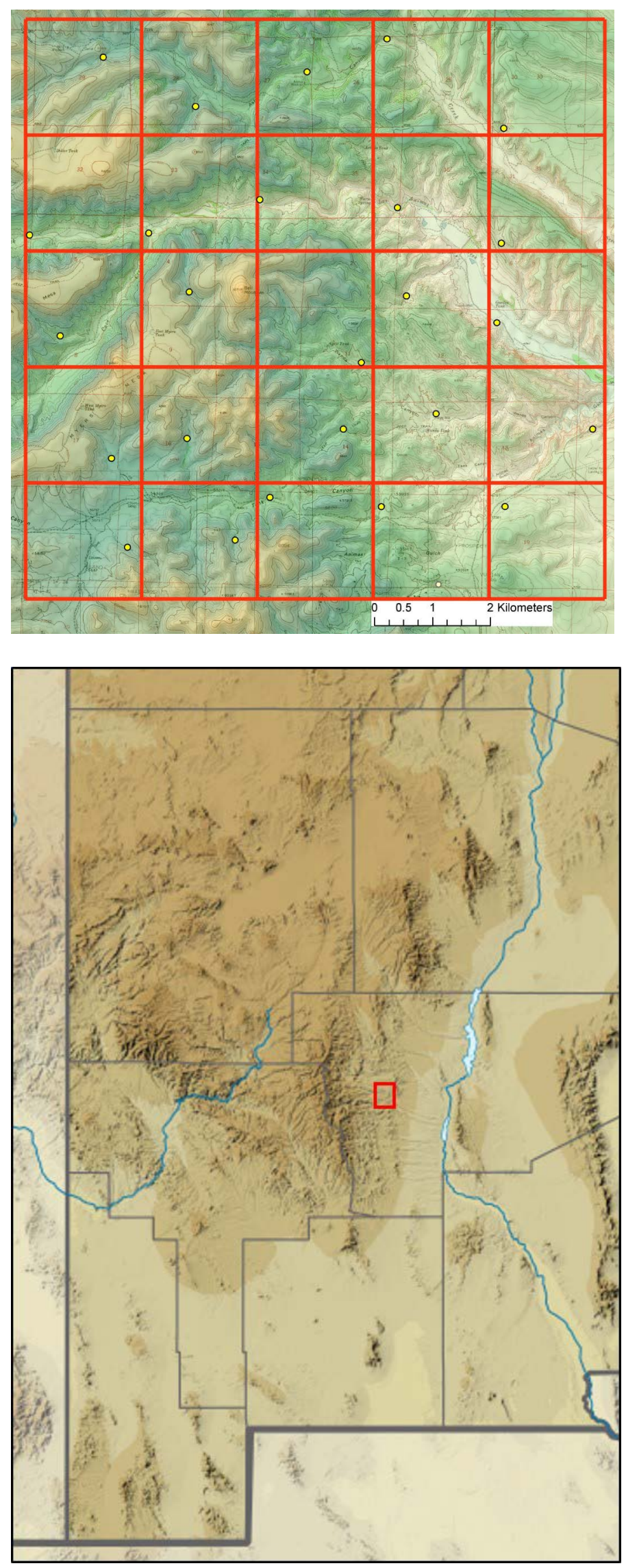

Figure 5. Camera-trap localities $(n=25)$ established across $100 \mathrm{~km}^{2}(10 \times 10 \mathrm{~km}$ grid) on the Ladder Ranch (2008-2012). Red outline indicates Ladder Ranch location within New Mexico. The New Mexico map is modified from original (USA New Mexico relief location map.svg). 
from four localities in the Gila), Arizona $(n=1)$, and Texas ( $n$ =6). Notiosorex cockrumi, N. tatticuli and Sorex cinereus were used to root the tree. For pocket mice, Perognathus flavus ( $n=17$ individuals from 15 localities), with P. flavescens as the outgroup. Lab procedures followed standard salt extraction methods (Fleming and Cook 2002), and amplification and Sanger sequencing methods for the entire cytb gene (1,140 base pairs; Hope et al. 2010), using the MSB05/ MSB14 primer set. Representative cytb sequences were downloaded from GenBank (https://www.ncbi.nlm.nih. gov/genbank/) to assess phylogeographic placement of Gila specimens (Appendix 1). To graphically examine geographic variation, phylogenetic trees were inferred under a Bayesian framework with Mrbayes 3.2.6 (Ronquist and Huelsenbeck 2003). A mixed model was used to sample all possible model space with rates set to a gamma distribution run for 1,000,000 generations sampling every 1,000 with two runs and four chains. Convergence of runs was determined by verifying that the standard deviation of split frequencies was below 0.01 after which trees were summarized to produce a $50 \%$ consensus tree following a 25 $\%$ burn-in and then manually rooted with the outgroup in FigTree 1.4.4 (Rambaut 2014).

Conservation status. We assess conservation status by compiling risk assessments across geographic scales, from global sources through the International Union for Conservation of Nature-IUCN (www.iucn.org) and Convention on International Trade on Endangered Species-CITES (https:// www.cites.org), to national through the Endangered Species Act-ESA (https://www.fws.gov/endangered/laws-policies), and regional through the New Mexico Department of Game and Fish-NMDGF (https://www.wildlife.state.nm.us/conservation/wildlife-species-information/threatened-and-endangered-species) following MacDonald and Cook (2007). We then assess species identified as being imperiled based on distributions or relative abundances found during this survey.

\section{Results}

Faunal composition. We documented 108 native mammal species in the Gila (104 extant; Table 1). This diversity of species is documented by 12,505 specimens held in 46 museum collections that span the period 1851 to 2020 . The majority of these specimens $(7,312 ; 58 \%)$ are archived at the MSB, including 2,919 specimens collected during this study (https://dx.doi.org/10.7299/X73B60G6). Rodents (74 \%) and bats (20\%) make up most of these specimens, and most of the rodents are in the families Cricetidae (69\%), Sciuridae (13\%) or Heteromyidae (11\%; Figure 6). Medium (beaver-sized) and larger game mammals continue to be poorly represented in museum collections (323 specimens across 15 species), although many are harvested (i. e., fur trapping, hunting) at high annual rates. Photographic data (Figure 7) from the camera-trap grid yielded data on medium and large mammals (Figure 8). Six species have been extirpated from the region including: Cynomys gunnisoni (last recorded by a museum voucher in 1972),
A

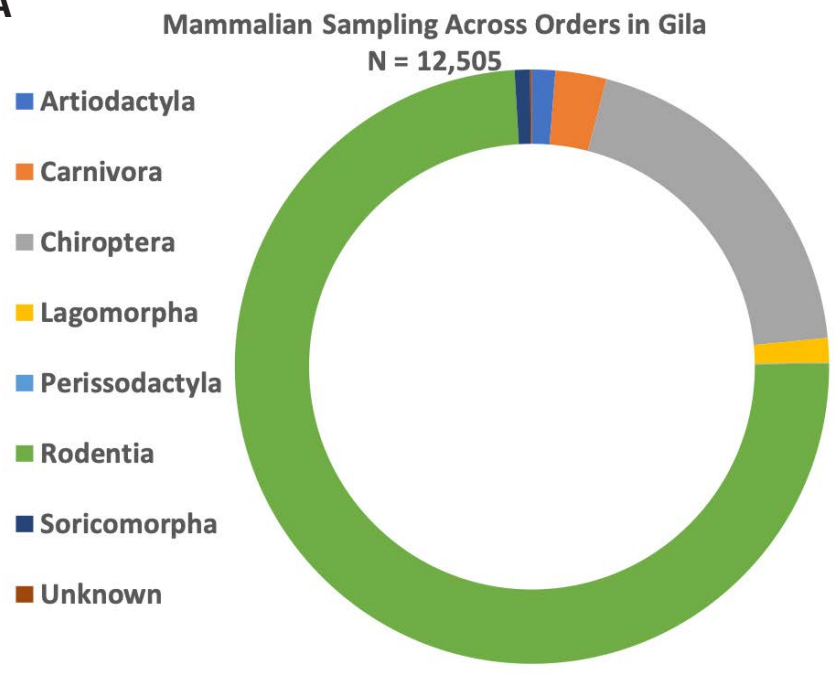

B

Sampling across Rodent Families in the Gila

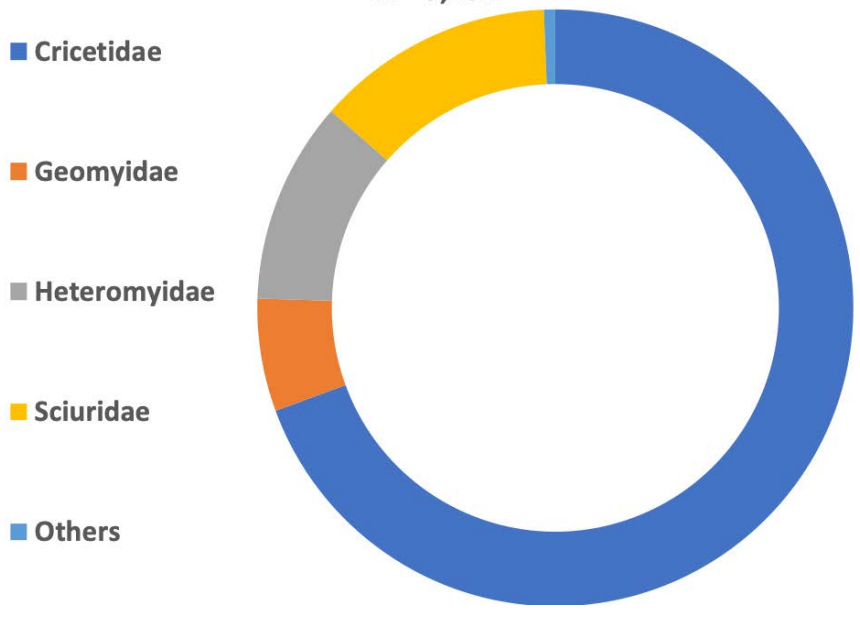

C

Mammalian Sampling Across Time in the Gila $\mathrm{N}=\mathbf{1 2 , 5 0 5}$

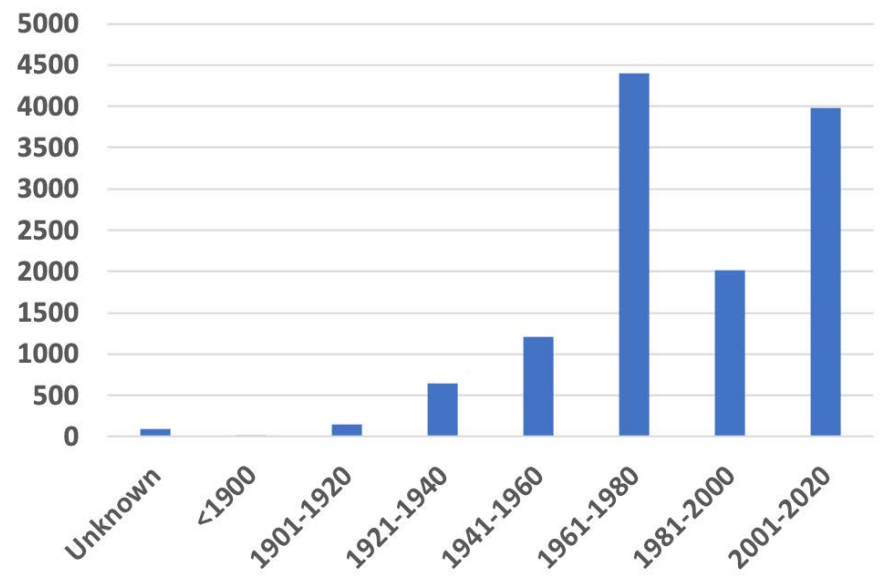

Figure 6. A) Concentration of taxonomic sampling (number of specimens) in the Gila across Mammalian orders. The vast majority of specimens represent the Order Rodentia and Order Chiroptera. B) Within the Order Rodentia, Cricetidae is the most commonly sampled family. C) Comparison of mammalian specimen acquisition across 20-year intervals shows that the periods 1961-1980 and 2001-2020 were the most intensively sampled. 


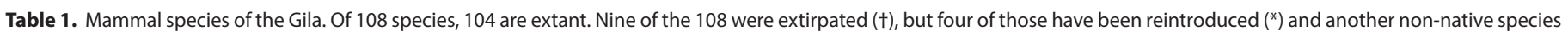
has been introduced (**). Prior taxonomic names, revised since Wilson and Reeder (2005), are provided (in parentheses).

\begin{tabular}{|c|c|c|}
\hline Order & Family & Species \\
\hline \multicolumn{3}{|c|}{ Artiodactyla (6) } \\
\hline \multicolumn{3}{|c|}{ Tayassuidae (1) } \\
\hline & & Pecari tajacu (Linnaeus, 1758) \\
\hline \multicolumn{3}{|c|}{ Cervidae (3) } \\
\hline & & ${ }^{*}$ Cervus canadensis Shaw, 1804 \\
\hline & & Odocoileus hemionus (Rafinesque, 1817) \\
\hline & & Odocoileus virginianus (Zimmerman, 1780) \\
\hline \multicolumn{3}{|c|}{ Antilocapridae (1) } \\
\hline & & Antilocapra americana (Ord, 1815) \\
\hline \multicolumn{3}{|c|}{ Bovidae (1) } \\
\hline & & *Ovis canadensis Shaw, 1804 \\
\hline \multicolumn{3}{|c|}{ Primates (1) } \\
\hline \multicolumn{3}{|c|}{ Hominidae (1) } \\
\hline & & Homo sapiens Linnaeus, 1758 \\
\hline \multicolumn{3}{|c|}{ Rodentia (51) } \\
\hline \multicolumn{3}{|c|}{ Sciuridae (12) } \\
\hline & & Ammospermophilus harrisii (Audubon \& Bachman, 1854) \\
\hline & & Callospermophilus (Spermophilus) Iateralis Say, 1823 \\
\hline & & †Cynomys gunnisoni (Baird, 1855) \\
\hline & & ${ }^{*}$ Cynomys ludovicianus (Ord, 1815) \\
\hline & & Ictidomys (Spermophilus) tridecemlineatus (Erxleben,1777) \\
\hline & & Neotamias (Tamias) cinereicollis (J.A. Allen, 1890) \\
\hline & & Neotamias (Tamias) dorsalis (Baird, 1855) \\
\hline & & Otospermophilus (Spermophilus) variegatus (Erxleben, 1777) \\
\hline & & Sciurus aberti Woodhouse, 1852 \\
\hline & & Sciurus arizonensis Coues, 1867 \\
\hline & & $\begin{array}{l}\text { Tamiasciurus fremonti (hudsonicus) (Audubon \&Bachman, } \\
\text { 1853) }\end{array}$ \\
\hline & & Xerospermophilus (Spermophilus) spilosoma (Bennett, 1833) \\
\hline \multicolumn{3}{|c|}{ Castoridae (1) } \\
\hline & & Castor canadensis Kuhl, 1820 \\
\hline \multicolumn{3}{|c|}{ Heteromyidae (9) } \\
\hline & & Chaetodipus baileyi (Merriam, 1889) \\
\hline & & Chaetodipus hispidus (Baird, 1858) \\
\hline & & Chaetodipus intermedius (Merriam, 1889) \\
\hline & & Chaetodipus penicillatus (Woodhouse, 1852) \\
\hline & & Dipodomys merriami Mearns, 1890 \\
\hline & & Dipodomys ordii Woodhouse, 1853 \\
\hline & & Dipodomys spectabilis Merriam, 1890 \\
\hline & & Perognathus apache (flavescens) Merriam, 1889 \\
\hline & & Perognathus flavus Baird, 1855 \\
\hline \multicolumn{3}{|c|}{ Geomyidae (1) } \\
\hline & & Thomomys bottae Eydoux \& Gervais, 1836 \\
\hline \multicolumn{3}{|c|}{ Dipodidae (1) } \\
\hline & & Zapus luteus (hudsonius) Miller, 1911 \\
\hline \multicolumn{3}{|c|}{ Cricetidae (25) } \\
\hline & & Baiomys taylori (Thomas, 1887) \\
\hline & & †Microtus drummondii (pennsylvanicus) (Ord, 1815) \\
\hline & & Microtus longicaudus (Merriam, 1888) \\
\hline & & Microtus mogollonensis (mexicanus) (Mearns, 1890) \\
\hline
\end{tabular}

\begin{tabular}{|c|c|c|}
\hline Order & Family & Species \\
\hline & & Microtus montanus (Peale, 1848) \\
\hline & & Myodes gapperi (Vigors, 1830) \\
\hline & & Neotoma albigula Hartley, 1894 \\
\hline & & Neotoma mexicana Baird, 1855 \\
\hline & & Neotoma micropus Baird, 1855 \\
\hline & & Neotoma stephensi Goldman, 1905 \\
\hline & & Ondatra zibethicus (Linnaeus, 1776) \\
\hline & & Onychomys arenicola Mearns, 1896 \\
\hline & & Onychomys leucogaster (Wied-Neuwied, 1841) \\
\hline & & Onychomys torridus (Coues, 1874) \\
\hline & & Peromyscus boylii (Baird, 1855) \\
\hline & & Peromyscus eremicus (Baird, 1857) \\
\hline & & Peromyscus gratus Merriam, 1898 \\
\hline & & Peromyscus leucopus (Rafinesque, 1818) \\
\hline & & Peromyscus sonoriensis (maniculatus) (Wagner, 1845) \\
\hline & & Peromyscus nasutus (J.A. Allen 1891) \\
\hline & & Peromyscus truei (Schufedlt, 1885) \\
\hline & & Reithrodontomys megalotis (Baird, 1857) \\
\hline & & Sigmodon fulviventer J.A. Allen, 1889 \\
\hline & & Sigmodon hispidus Say \& Ord, 1825 \\
\hline & & Sigmodon ochrognathus V. Bailey, 1902 \\
\hline \multicolumn{3}{|c|}{ Muridae (1) } \\
\hline & & ${ }^{* *}$ Mus musculus (Linnaeus, 1758) \\
\hline \multicolumn{3}{|c|}{ Erethizontidae (1) } \\
\hline & & Erethizon dorsatum (Linnaeus, 1758) \\
\hline
\end{tabular}

Lagomorpha (3)

Leporidae (3)

Lepus californicus Gray, 1837

Sylvilagus audubonii (Baird,1857)

Sylvilagus floridanus (J.A. Allen, 1890)

Eulipotyphla (Soricomorpha) (3)

Soricidae (3)

Notiosorex crawfordi (Coues, 1877)
Sorex merriami (Dobson, 1890)
Sorex monticola Merriam 1890

Chiroptera (23)

Phyllostomidae (1)

Leptonycteris yerbabuenae Miller, 1900

Molossidae (2)

Nyctinomops macrotis (Gray, 1840)

Tadarida brasiliensis (I. Geoffroy, 1824)

Vespertilionidae (20)

Aeorestes cinereus Palisot de Beauvois, 1796

Antrozous pallidus (Le Conte, 1856)

Corynorhinus townsendii (Cooper, 1837)

Eptesicus fuscus (Beauvois, 1796)

Euderma maculatum (J.A. Allen, 1891)

Idionycteris phyllotis (G.M. Allen, 1891)

Lasionycteris noctivagans (Le Conte, 1831)

Lasiurus blossevillii (Lesson \& Garnot, 1826) 
Table 1. Continuation....

\begin{tabular}{|c|c|c|}
\hline Order & Family & Species \\
\hline & & Lasiurus borealis (Müller, 1776) \\
\hline & & Myotis auriculus (Baker \& Stains, 1955) \\
\hline & & Myotis californicus (Audubon \& Bachman, 1842) \\
\hline & & Myotis carissima Thomas, 1904 \\
\hline & & Myotis ciliolabrum (Merriam, 1886) \\
\hline & & Myotis evotis (H. Allen, 1864) \\
\hline & & Myotis occultus Hollister, 1909 \\
\hline & & Myotis thysanodes Miller, 1897 \\
\hline & & Myotis velifer (J.A. Allen, 1890) \\
\hline & & Myotis volans (H. Allen, 1866) \\
\hline & & Myotis yumanensis (H. Allen, 1864) \\
\hline & & Nycticeius humeralis (Rafinesque, 1818) \\
\hline & & Parastrellus (Pipistrellus) hesperus H. Allen, 1864 \\
\hline \multicolumn{3}{|c|}{ Carnivora (19) } \\
\hline \multicolumn{3}{|c|}{ Felidae (3) } \\
\hline & & Lynx rufus (Schreber, 1777) \\
\hline & & Puma concolor (Linnaeus, 1771) \\
\hline & & †Panthera onca (Linnaeus, 1758) \\
\hline \multicolumn{3}{|c|}{ Canidae (4) } \\
\hline & & Canis latrans Say, 1823 \\
\hline & & ${ }^{*}$ Canis lupus Linnaeus, 1758 \\
\hline & & Urocyon cinereoargenteus (Schreber, 1775) \\
\hline & & Vulpes macrotis Merriam, 1888 \\
\hline \multicolumn{3}{|c|}{ Ursidae (2) } \\
\hline & & Ursus americanus Pallas, 1780 \\
\hline & & †Ursus arctos Linnaeus, 1758 \\
\hline \multicolumn{3}{|c|}{ Mustelidae (3) } \\
\hline & & †Lontra canadensis (Schreber, 1777) \\
\hline & & Mustela frenata Lichtenstein, 1831 \\
\hline & & †Mustela nigripes (Audubon \& Bachman, 1851) \\
\hline & & Taxidea taxus (Schreber, 1777) \\
\hline \multicolumn{3}{|c|}{ Mephitidae (4) } \\
\hline & & Conepatus leuconotus (Lichtenstein, 1832) \\
\hline & & Mephitis macroura Lichtenstein, 1832 \\
\hline & & Mephitis mephitis (Schreber, 1776) \\
\hline & & Spilogale leucoparia (gracilis) Merriam, 1890 \\
\hline \multicolumn{3}{|c|}{ Procyonidae (3) } \\
\hline & & Bassariscus astutus (Lichtenstein, 1830) \\
\hline & & Nasua narica (Linnaeus, 1766) \\
\hline & & Procyon lotor (Linnaeus, 1758) \\
\hline
\end{tabular}

Microtus drummondii (last voucher from 1915), Panthera onca (no voucher specimen), Ursus arctos (no voucher specimen), Lontra canadensis (last voucher from 1933), and Mustela nigripes (last voucher from 1915). Four other species were extirpated and subsequently reintroduced (Cynomys ludovicianus, last recorded by a museum voucher specimen in 1936, reintroduced in 1997; Canis lupus baileyi, last voucher from 1925, reintroduced in 1998; Cervus canadensis, last voucher from 1900, reintroduced 1910; and Ovis canadensis, no voucher, reintroduced 1964).
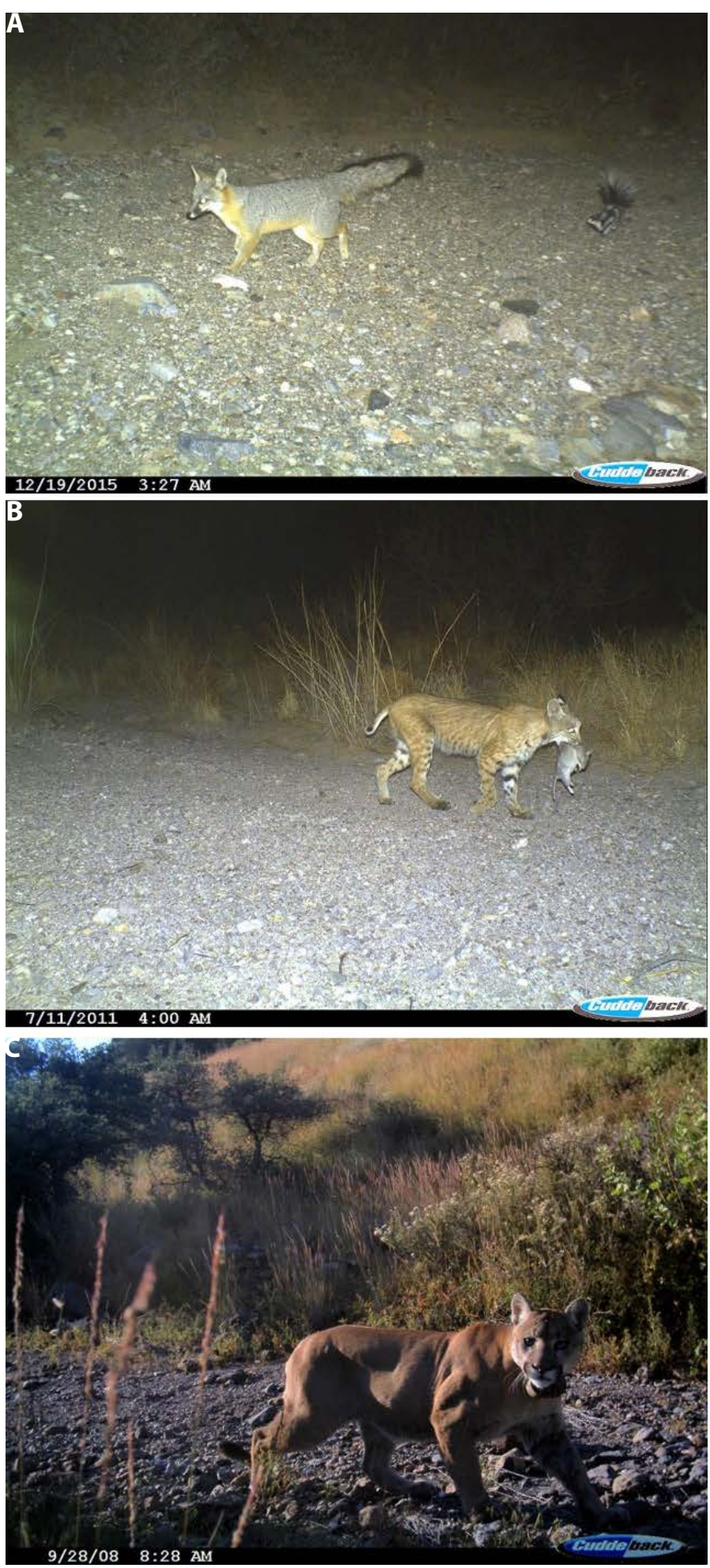

Figure 7. Photos from Ladder Ranch camera trap array documenting species occurrences as well as interactions among species. a) Grey fox (Urocyon cinereoargenteus) and spotted skunk (Spilogale leucoparia) were documented travelling together on many occasions; b) bobcat (Lynx rufus) carrying woodrat (Neotoma sp.) prey (other prey items documented included black-tailed jackrabbits, cottontail rabbits, kangaroo rats, rock squirrels; c) puma (Puma concolor) are one of the apex predators of the Gila.

Dates of extirpation based on museum vouchers represent a minimum estimate, as wild but uncollected populations may have persisted later. A single introduced species, Mus musculus, persists in the wild. We did not directly address several domesticated species that now have significant ecological roles in some ecosystems (e. g., cattle, Bos taurus). 


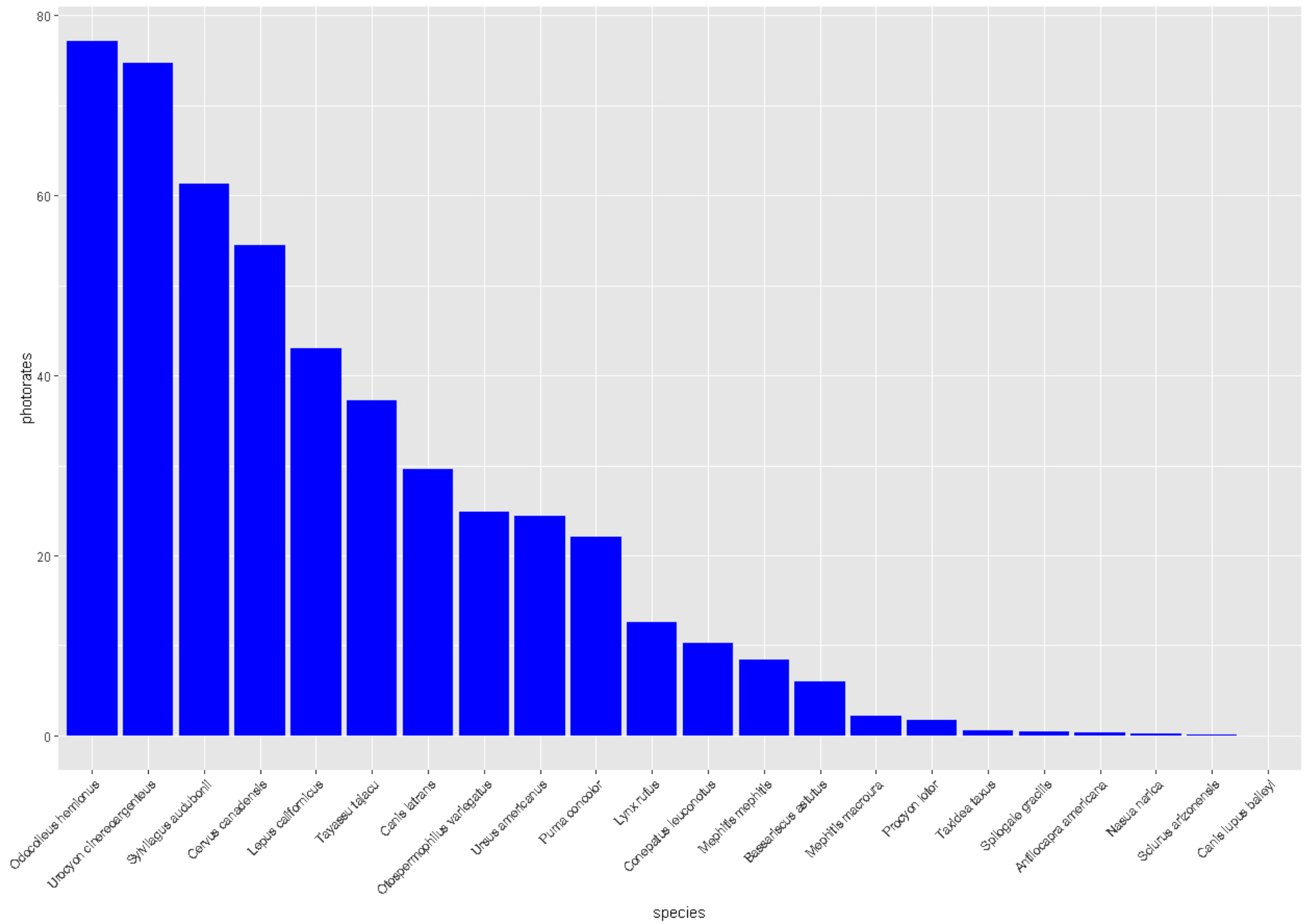

Figure 8. Photo capture rate of large and medium mammal species recorded from 25 cameras covering $100 \mathrm{sq} \mathrm{km}$ at a density of 1 per $4 \mathrm{sq} \mathrm{km}$. A $16-\mathrm{camera}$ grid was established in 2008 and expanded to 25 cameras in 2009. Cameras have been operated continuously since that time, for a total sampling effort of 81,293 camera nights through 2020. Photo rates in the figure are per 1,000 camera nights.

Phylogeographic analyses. We examined four species groups to detect potential endemism in the Gila or the possibility that multiple clades converged in this region. For white-throated woodrats, two major clades within $N$. albigula appear to converge in the Gila. A northeastern clade includes specimens from McKinley, Socorro, and Otero counties and the northern end of Sierra County in New Mexico, and a southwestern clade includes all specimens from Arizona, Chihuahua, and from the southern end of Sierra County (Figure 9).

For desert shrews, Notiosorex crawfordi and N. cockrumi both occur in sympatry in nearby Pima County, Arizona (adjacent to the Gila; Figure 10), but we did not detect the latter in the Gila. These two species, along with N. tataticuli, form an unresolved trichotomy (although similarity is slightly higher between the two most distant species, $N$. crawfordi and $N$. tataticuli, at $P P=0.87$ ). In this case, there appears to be little phylogeographic structure within $N$. crawfordi across Arizona, New Mexico, and Texas.

For pocket gophers, we obtained multiple unresolved clades that form a polytomy within T. bottae. Most of the Gila specimens clustered with a specimen from the nearby
Graham Mountains in Arizona and this distinctive clade was the only grouping found in the Gila to date (Figure 11), although more extensive geographic sampling of this polymorphic species is needed to better understand evolutionary relationships and biogeographic history of this ecologically important clade of mammals.

With regard to silky pocket mice, there appear to be two clades of $P$. flavus that converge in the Gila region (Figure 12). Representatives of these clades apparently are syntopic in Sierra and Catron counties. Specimens from those counties and Grant County form a southwestern clade along with specimens from southern Arizona and northern Chihuahua. Other specimens examined from Sierra and Catron counties are united in a northeastern clade with specimens from central Arizona, west Texas, and Oklahoma. This latter clade is weakly united $(P P=0.87)$ with specimens from southeastern New Mexico and west Texas.

\section{Discussion}

Faunal composition. With 104 extant species, the Gila supports one of the most diverse mammalian faunas in North America north of the USA-Mexico border. It includes nearly 
two-thirds of all the mammalian species known for New Mexico (Malaney et al. 2021), and exceeds state-wide totals for 38 states in the United States (https://www.mammalogy.org/mammals-list). The addition of six more species to the Gila inventory in the last decade suggests the area harbors even higher mammalian diversity than documented here. The paucity of sampling and uneven distribution of specimens (Figure 3a) suggests more site intensive and broad spatial sampling has the potential to reveal further unrecorded taxa. Only six areas (hexagonal grids $=541$ $\mathrm{km}^{2}$ ) within the region contain more than 500 specimens summed across all species. The most well sampled region in the Gila (Willow Creek area with 1,992 specimens) equates to fewer than four specimens per $\mathrm{km}^{2}$ summed for all species. The majority contain far less, ranging from 0.02 to 0.87 specimens per $\mathrm{km}^{2}$ documenting the entire temporal span of the past 170 years (Figure 3a). Most areas did not have sufficient specimens across a temporal scale for any single species to effectively assess environmental change through time (Figure 3b-d).

More than a third (35) of the 104 mammal species recorded in the Gila reach their distributional range limit within the Gila (Figure 13), reflecting the position of the Gila at the confluence of distinct physiographic provinces and biomes. A number of other species have distributions that are peripheral to the Gila region and may be recorded there in the future. For example, two heteromyid rodents (Chaetodipus eremicus, Perognathus flavescens) and two cricetid rodents (Reithrodontomys montanus, Sigmodon arizonae) occur in the surrounding lowlands. Intensive inventories for shrews are lacking for the Gila and some taxa may yet to be recorded, including the western water shrew, Sorex navigator, which has been collected from the adjacent White Mountains in Arizona. Fossil records of Vulpes vulpes exist from the Gila and recent specimens have been collected just west of the region, near Dusty, New Mexico. The northern limits of a number of bat species (Eumops perotis, Nyctinomops femorosaccus, Choeronycteris mexicana, Leptonycteris nivalis, and Dasypterus xanthinus) occur in the Bootheel region of New Mexico (Hidalgo County) within $100 \mathrm{~km}$ of the Gila. The cottontails collected in ponderosa pine forest in the Gila were tentatively referred to S. floridanus, following Hoffmeister (1986) and Findley et al. (1975); however, we emphasize that the definitive identity of these higher elevation lagomorphs in the Gila awaits detailed taxonomic investigation. Whether they are this species, or Sylvilagus cognatus, S. nuttallii, S. holzneri, or a new species remains unknown (Hoffmeister and Lee 1986; Ruedas 1998). Panthera onca has been sighted in several nearby mountain ranges along the border and may well be found again in the Gila in the near future.

Regional historical biogeography. Although the geographic position, complex topography, and dynamic geological and climatic history of the Gila have played the primary roles in assembling this diverse fauna, additional phylogeographic (e. g., Duran et al. 2012; Malaney et al. 2012) and paleontological analyses in the future likely will yield new insights into this dynamic biogeographic

\section{Neotoma}

Bayesian analysis performed on

1140 base pairs of cytochrome $b$

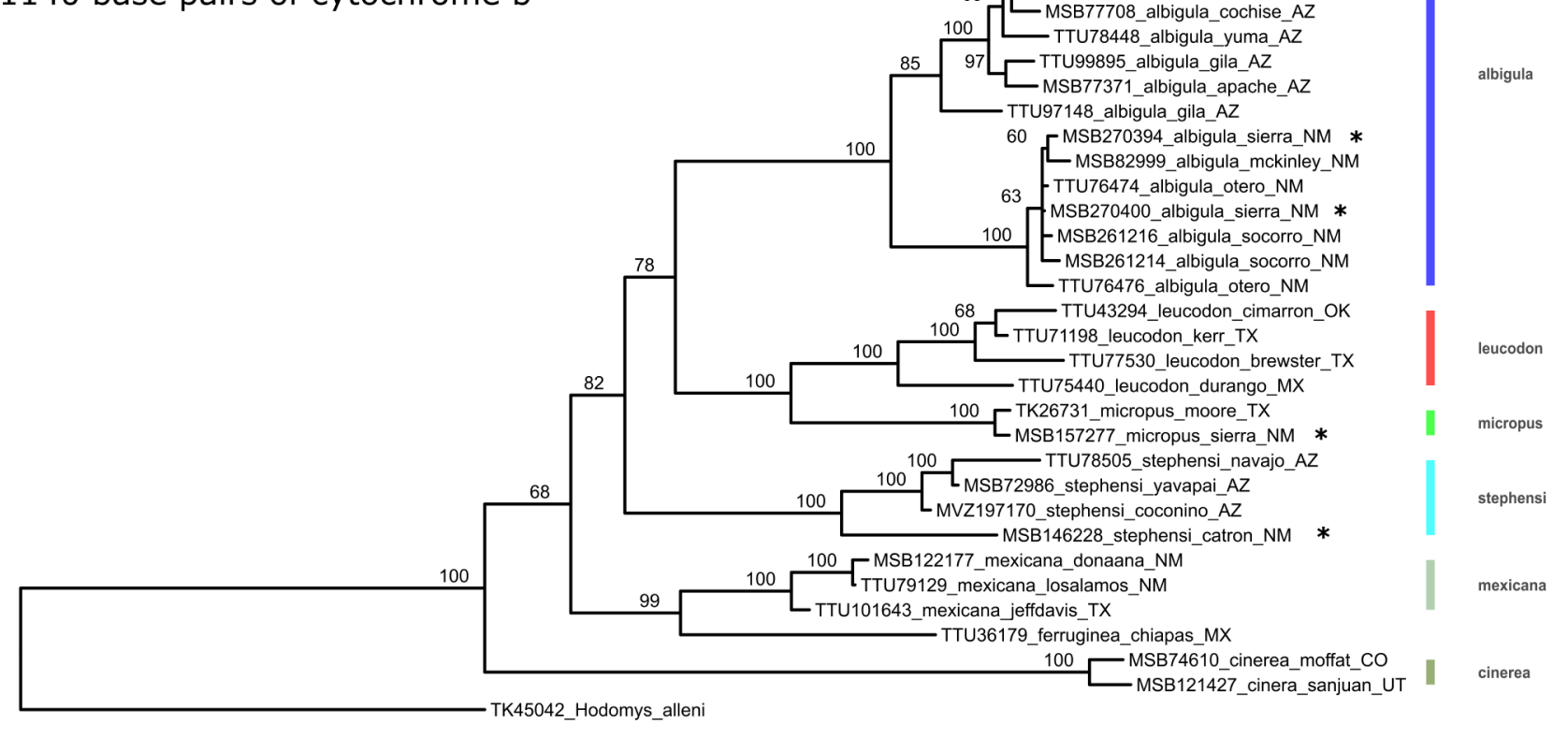

Figure 9. Phylogenetic placement of Neotoma albigula from southwestern New Mexico inferred under a Bayesian framework using 1140 base pairs of the mitochondrial cytochrome

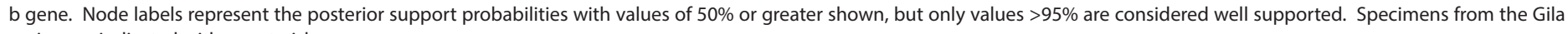
region are indicated with an asterisk. 
history. Desertification in the Southwest began in the Tertiary and continued into the Neogene with mountain uplift, creating rain shadows and deserts (Riddle 1995). During the Oligocene, dry tropical habitats were replaced with seasonal dry woodlands and savannas (Riddle 1995). With the uplift of the Sierra Madre Occidental and Colorado Plateau, and more local block-faulting of the Basin and Range province during the middle Neogene, diversity and provinciality of these faunas increased in western North America (Riddle et al. 2000). During the Miocene and Pliocene, three provinces that meet near the Gila (Basin and Range, Colorado Plateau, and Mexican Plateau/Chihuahuan desert) and their corresponding habitats (semi-desert/ woodland, grassland/savannah, semi-desert/sub-tropical, respectively) were dynamically assembled and evolving (Riddle 1995). Episodic events during glacial-interglacial cycles of the Pleistocene set the stage for contraction and expansion of populations that led to divergence of many lineages of southwestern mammals (Conroy and Cook 2000; Jezkova et al. 2009; Andersen and Light 2012).

High biotic diversity in both montane and desert habitats of the Gila is likely the result of vicariance that fragmented species distributions and led to subsequent divergence of populations during shifting pluvial-interpluvial periods of the Pleistocene (Findley 1969; Patterson 1980; Riddle and Hafner 2006). This cyclic history of expansion and contraction, followed by isolation and divergence can be seen today in the disjunct distributions of high-elevation, montane populations of species such as Myodes gapperi, Callospermophilus lateralis, Tamiasciurus fremonti, and Sciurus aberti (Findley et al. 1975).

Fossil record. Nineteen paleontological sites in the Gila that span a period from the Eocene to the Pleistocene (https://www.utep.edu/leb/pleistNM/default.htm) illustrate both the rich fossil history of the region as well as distributional shifts. Schollmeyer and MacDonald (2020) added records of faunal remains from an additional 90 (of their total 105) archaeological sites from this region that range in age from $2000 \mathrm{BC}$ to $A D$ 1450. From all these sites, 137 mammal specimens representing nine mammalian orders have been identified including: Eulipotyphla $(n=4)$, Pilosa and Cingulata ( $n=3)$, Chiroptera $(n=1)$, Carnivora $(n=18)$, Artiodactyla $(n=29)$, Perissodactyla $(n=24)$, Proboscidea $(n=14)$, Rodentia $(n=35)$, and Lagomorpha $(n=9)$, representing 28 extant and 51 extinct taxa (Stearns 1942; Cosgrove 1947; Wills 1988; Morgan 2015; Morgan et al. 2011; Schollmeyer and MacDonald 2020). Specimens of extant mammals not currently found in the Gila include Marmota flaviventris, Urocitellus elegans, Cynomys gunnisoni, Cratogeomys castanops, Geomys arenarius, Thomomys talpoides, Neotoma cinerea, Microtus drummondii (extirpated in the last ca. 50 years), Sylvilagus nuttallii, Vulpes vulpes, and Vulpes velox, and some of these document changes that have occurred since the Last Glacial Maximum.

Phylogeographic analyses. For the four selected species that we examined using cytochrome- $b$ sequences, we found variable phylogeographic patterns. One species shows a single phylogeographic clade largely centered on the Gila (T. bottae), another (N. crawfordi) was shown to be closely related to populations to both the east and west of the Gila, and two species (N. albigula and P. flavus) were shown to have multiple clades that converged in the Gila.

Edwards et al. (2001) recognized $N$. leucodon to represent N. albigula east of the Río Grande, based on sequence analysis of the mtDNA cytb gene. Bradley and Mauldin (2016) suggested that populations from McKinley and Otero counties in New Mexico (spanning the Río Grande) may represent a third species, based on cytb divergence of $6.2 \%$. Derieg et al. (2021) reexamined the two species using multiple nuclear loci in addition to cytb, and instead concluded that the distinction between the two taxa was the result of mitochondrial introgression from an unsampled, or perhaps a now-extinct, lineage related to $N$. micropus into the eastern form of N. albigula (nominally N. leucodon). Neotoma leucodon is minimally differentiated from N. albigula across nuclear loci and therefore represents either a recent divergence or is conspecific. The two clades that we recovered within N. albigula (Figure 9) do not conform with clades recovered by Edwards et al. (2001), but instead sort into northeastern and southwestern clades that roughly are parallel to, but north of, the Mogollon Rim.

There is no phylogeographic structure within specimens of N. crawfordi across the Gila (Figure 10). Similarly, the distinctive phylogeographic clade of $T$. bottae of the Gila (Figure 11) suggests the possibility of finding other endemic taxa from the region. Patton and Smith (1990) and Smith and Patton (1988) found that southwestern New Mexico populations ultimately related to the widespread Basin and Range genetic group that extends from southern California to southeastern Coahuila. The boundary between the Basin and Range and Great Basin clades of T. bottae (Smith and Patton 1988) also approximates the boundary between two clades of $N$. albigula we identified. The two paraphyletic clades recovered within P. flavus (Figure 12) in the Gila are consistent with an east-west split although representatives of each clade are found in both Catron and Sierra counties. The northeastern and southeastern clades represent the Southern Rockies/ Colorado Plateau clade and the Northern Chihuahuan clades, respectively, of Neiswenter and Riddle (2010).

Relatively few recent phylogeographic studies of Southwestern mammals have included representative specimens from the Gila, likely because the region is marginal to the various biomes that converge there. However, this edge dynamic makes the Gila a critical region for the examination of interactions among expanding lineages and species. Surveys of the literature reveal only 11 published phylogeographic studies of mammals to date that we are aware of that include samples from the Gila. These studies are: Lynx rufus (Reding et al. 2012), Ursus americanus (Van den Bussche et al. 2009), Microtus mogollonensis (Crawford et al. 2011), Onychomys arenicola (Riddle 1995), Peromyscus maniculatus (Dragoo et al. 2006), Chaetodipus hispidus 
(Andersen and Light 2012), Chaetodipus penicillatus (Jezkova et al. 2009), Perognathus flavus (Neiswenter and Riddle 2010), Neotamias cinereicollis and N. dorsalis (Sullivan et al. 2014), Tamiasciurus fremonti (Hope et al. 2016), and Sciurus aberti (Lamb et al. 1997). Our analyses of Notiosorex crawfordi, Neotoma albigula, Perognathus flavus, and Thomomys bottae expand the spatial and temporal views of biotic variation in the Gila and highlight the region's potential for more detailed examination of contact zone dynamics. Further, the possibility of endemic populations in this region requires further focus and investigation.

Conservation status. Frey (2010) identified mammalian species of potential concern in the Gila and included mammals from Apache and Greenlee counties in Arizona and Luna and Hidalgo counties in New Mexico. Modifying the methods of Yu and Dobson (2000), she assessed aspects of rarity, concluding that $>90 \%$ of the mammal species of the Gila should be classified at some level of rarity, with $50 \%$ at risk for habitat loss (Frey 2010). This preliminary approach has merit, but only when based on robust documentation of the distribution and status of species in the Gila. Lacking such documentation, the relatively high levels of apparent rarity may primarily reflect insufficient field work (Malaney and Cook 2018). For example, we recorded three of the 11 species considered by Frey (2010) as "extremely rare" at multiple localities: Myotis evotis (five localities), Myotis auriculus (three localities), and Peromyscus nasutus (two localities, restricted to rocky substrate).
Using conservation criteria across formal international to statewide risk assessments and new data gathered in this study, we concluded that nine extant and one extirpated species should be considered for immediate (or reinvigorated) conservation assessment and monitoring (see beyond). These represent about $10 \%$ of the species identified in this study, but we acknowledge that many species remain data deficient.

Euderma maculatum was designated as "Threatened" by NMDGF in 1988, although Geluso (2017) reported the persistence of this species at many sites in his 2006 resurvey of historic sites of occurrence in New Mexico. He found this species at seven sites in the Gila based on audible calls. Hayward and Hunt (1972) stated that E. maculatum is a late-night flyer (after midnight), which could conceal detection because nets are often closed before midnight. The spotted bat is a mid-elevation bat in the Gila (1,850 to $2,450 \mathrm{~m}$ ), usually occurring in ponderosa pine and mixed conifer forests, and usually within $1.5 \mathrm{~km}$ of rocky outcroppings and cliffs where they likely roost (Findley et al. 1975). In Arizona, spotted bats are often captured in riparian areas near cliffs and rocks (Hoffmeister 1986). Hayward and Hunt (1972) caught one specimen in their 1972 survey of the Gila Wilderness and Jones (1965) reported that he captured one during his survey of the Mogollon Mountains, in ponderosa pine forest near the town of Mogollon. One of the few Gila specimens (WNMU: Mamm:1842) was found on a screen door in May at Lake Roberts. The spotted bat is listed on

\section{Notiosorex}

Bayesian analysis performed on

1140 base pairs of cytochrome $b$

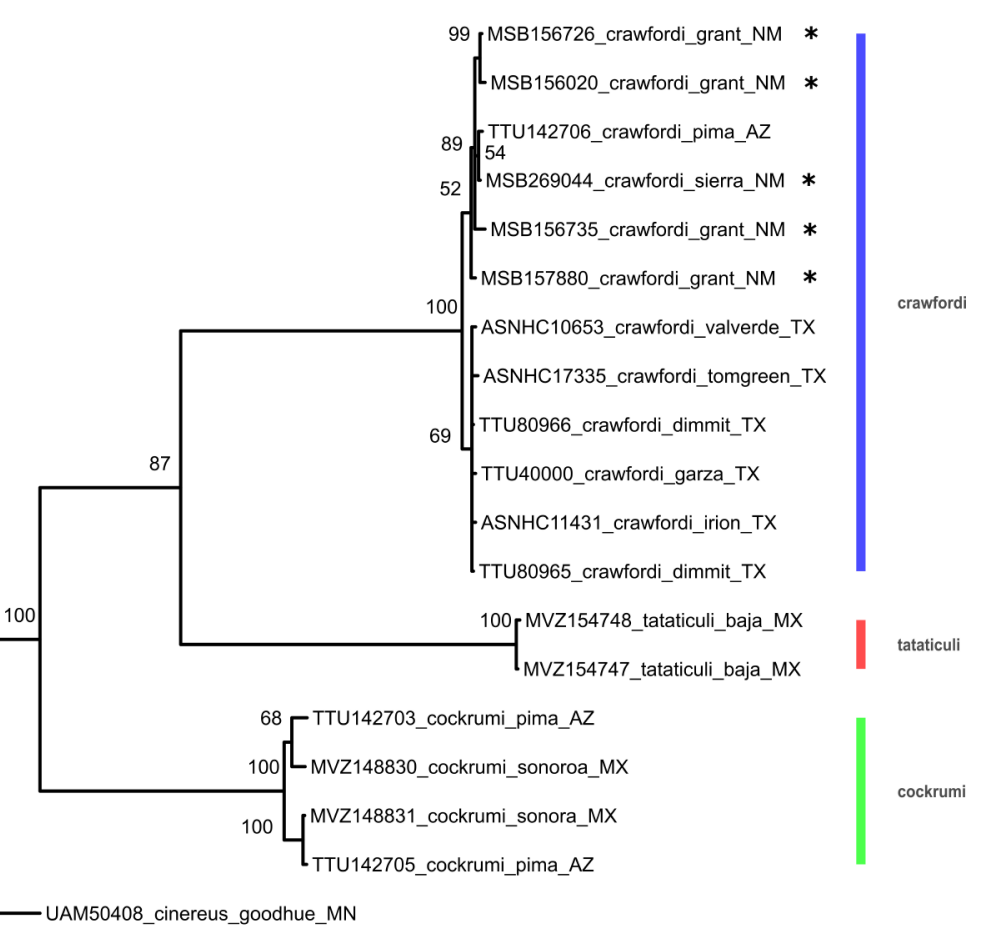

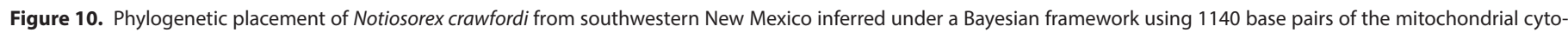

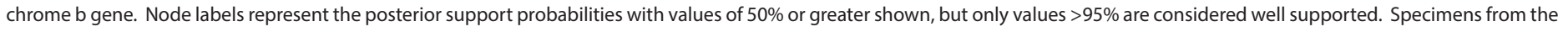
Gila region are indicated with an asterisk. 


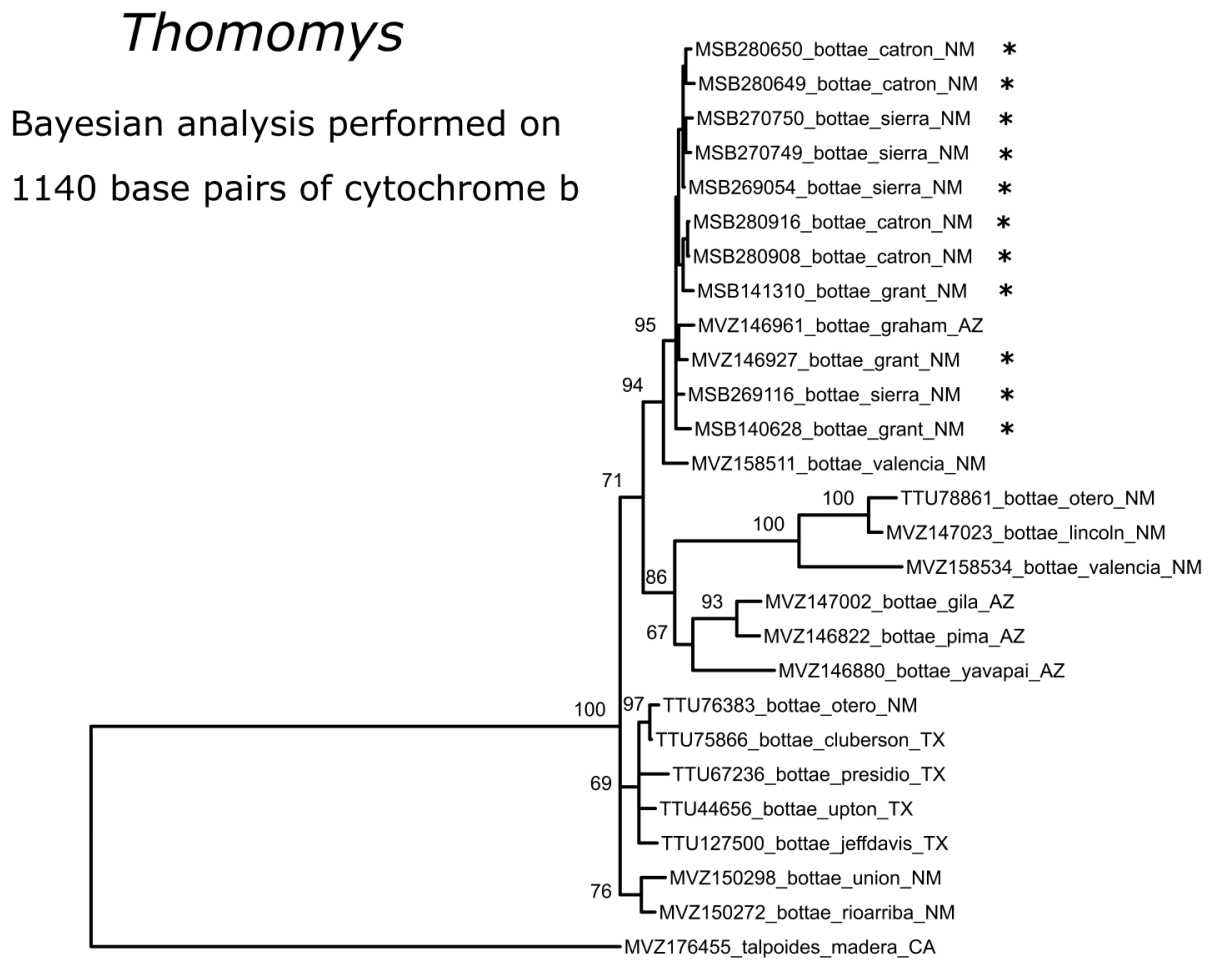

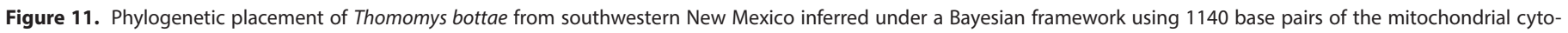

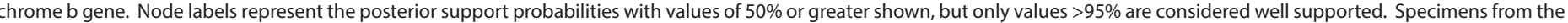
Gila region are indicated with an asterisk.

the US Fish and Wildlife Service's Species of Concern List (O'Shea et al.2018), as Threatened by the NMDGF, but Least Concern by the IUCN.

The migratory Lasiurus blossevillii is recommended for additional conservation study, although it has not been mentioned previously in conservation assessments. Although other migratory tree bats are found in moderate numbers (Aeorestes cinereus, $n=20$, and Lasionycteris noctivagans, $n=40$ ), only five $L$. blossevillii have been captured in the Gila. The two taken in 2013 were a male and a female captured in early April (MSB: Mamm: 267123, MSB: Mamm: 267125) and likely early migrants, as they represent the earliest annual record in New Mexico. Western red bats are usually found in riparian areas (Ammerman et al. 2012), consistent with the two we captured in cottonwood riparian areas on Animas Creek, just east of Ladder Ranch Headquarters. Hayward captured a female (WNMU: Mamm: 6615) in Reserve in ponderosa pine habitat.

Leptonycteris yerbabuenae is reported for the first time from the Gila. Cook (1986) reported L. yerbabuenae in the Animas Mountains. Hoyt et al. (1994) summarized records for Leptonycteris in New Mexico, noting that L. yerbabuenae and $L$. nivalis were found in the Peloncillo Mountains and Animas Mountains. Bogan et al. (2017) reported L. yerbabuenae from the Big Hatchet Mountains farther east in Hidalgo County. In September 2016, a resident living near Bill Evans Lake southeast of Cliff recorded a video of nectar bats swarming her hummingbird feeder (K. Beckenbach, pers. comm.) and in October 2018 recovered a specimen (MSB: Mamm: 333977) that died of unknown causes at her home. In September 2019, Keith Geluso documented a lesser long-nosed bat just east of the Gila Post Office (MSB: Mamm: 328326). These newer records may indicate an ongoing distributional expansion or this species simply was not previously detected, but given Bruce Hayward's longterm monitoring of bats in this area, the former hypothesis seems more likely. Lesser long-nosed bats were recently removed from the Endangered Species List (USFWS 2019), but populations should continue to be monitored and documented.

Zapus luteus is reported for the first time from the Gila and this new record (Malaney et al., submitted) may indicate a range expansion from the nearest source populations in the White and Mogollon mountains of Arizona (Hoffmeister 1986) as close as $15 \mathrm{~km}$ away, however limited sampling in the western Gila may also explain why this species was not previously detected. Hoffmeister (1986) reported 63 specimens from ten localities in the White and Mogollon Mountains on the nearby Mogollon Plateau. Malaney et al. (2012) predicted that the jumping mouse could occur in the Mogollon Mountains and Black Range of New Mexico based on species distribution modeling. This species occurs in riparian, mesic habitats at both high and low elevations (Malaney et al. 2012). Given these discoveries, a more thorough sampling effort to determine the geographic distribution of the New Mexico jumping mouse in the Gila is warranted. The seasonal habits of Zapus restrict fieldwork because they go into hibernation in late September or early October, seeking hibernacula in higher ground above their usual streamside habitat, and remain in hibernation until 
April or May. We and others have found jumping mice to be more readily captured in Museum Special traps than in Sherman live traps, so live traps set in the wrong season, or in the wrong habitat after they have begun moving towards hibernacula, are likely to be unsuccessful. Currently listed as federally Endangered, a more thorough sampling of their geographic distribution in the Gila is warranted (Malaney et al. submitted).

Canis lupus is listed by CITES as a species that may not currently be threatened with extinction but could become so (https://www.cites.org/eng/app/index.php). The Mexican wolf (Canis lupus baileyi) is listed as Endangered by NMDGF and the ESA. Mexican gray wolves were extirpated from the Gila, the region of their greatest historical abundance (Robinson 2005) by 1925 with the last recorded specimen from the Gila from $24 \mathrm{~km}$ SE Reserve on 11 May 1925 (USNM:245841). Plans to recover Mexican gray wolves began in 1977 and were executed in 1998 with the release of 11 wolves into the Blue Range of the Gila Wilderness as an experimental population (Hedrick and Frederickson 2008; USFWS 2010, 2015, 2017). According to a recent quarterly update (October-December 2020, USFWS 2020), there are at least 87 wolves that primarily roam the Gila in New Mexico, but they also venture into the Cibola National Forest and the San Mateo Mountains of Socorro County.

Another large carnivore native to the Gila, Panthera onca, was extirpated from the region in the last century, but could potentially recolonize from the south with an ever- increasing population in northern México and an increasing number of camera trap records from the Animas, Peloncillo, Chiricahua and other sky island mountain ranges just south of the Gila. There are jaguar petroglyphs present on rock faces within the Gila and numerous historic records (photos, accounts, and specimens) document jaguar occurrence far north of US Interstate 10 (I-10) from the late 1800s through the 1960s. One specimen held in the Smithsonian (USNM 289015) was collected by a U.S. Biological Survey hunter from the White Mountain Apache Indian Reservation in Arizona just west of the Gila. Others include animals killed near the Grand Canyon. USFWS (1994) acknowledged that a minimum of 64 jaguars have been killed in Arizona since 1900. Camera trap data have recorded regular use of the mountains in SE Arizona and SW New Mexico in the past two decades (McCain and Childs 2008). To date, those observed were males.

USFWS (2018) restricted the northern edge of the Northwestern Jaguar Recovery Unit to areas south of US I-10 and suggested the carrying capacity for jaguars within the US was only six animals. Sanderson et al. (2021) reevaluated previous models and assessments and concluded that ample suitable habitat extends northward into central Arizona and New Mexico, including the Gila region. They suggested that the carrying capacity within the US is from 90-151 animals, which could be sufficient for maintaining a viable population north of the international border wall. Their findings suggest that conservation efforts should not only focus on connectivity between Mexican and US populations but also

\section{Perognathus}

Bayesian analysis performed on

1140 base pairs of cytochrome $b$

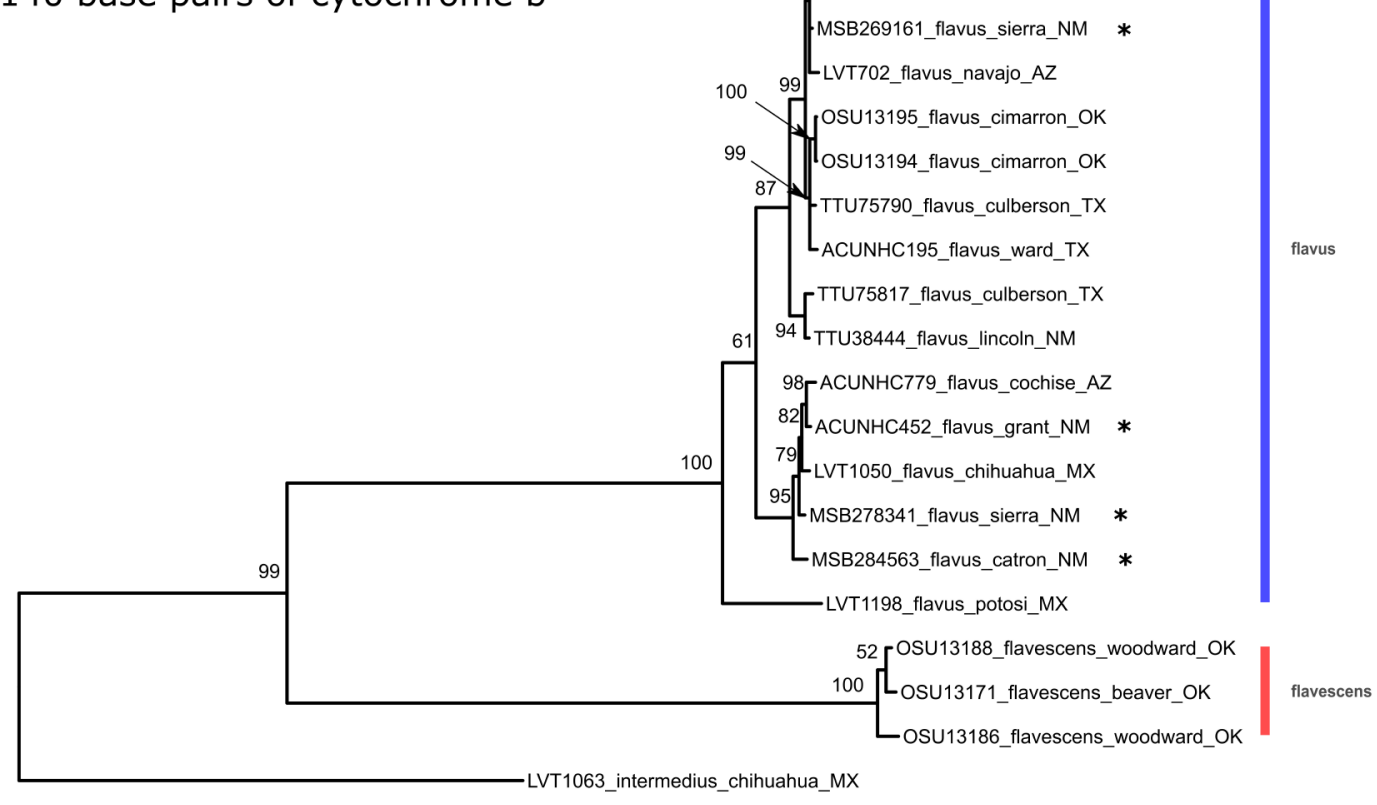

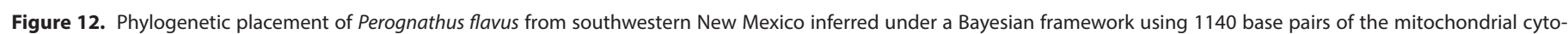

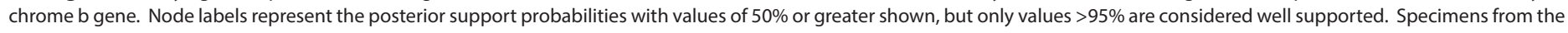
Gila region are indicated with an asterisk. 
in the re-establishing a self-sustaining population within a proposed Central Arizona/New Mexico Recovery Area (Sanderson et al. 2021) including the Gila region.

Microtus montanus arizonensis was listed as Endangered by NMDGF in 1979 and in 2008 NMDGF attempted to implement a recovery plan for $M$. montanus, but those plans were not formally approved. The threat is listed in terms of pressures on an already small, isolated population including anthropogenic activities (e. g., grazing, water diversion, and wetland conversion) as well as projected diminished habitat due to climate change (NMDGF 2020). There were 11 records from Catron County (two localities) before 1994, and 15 from Catron County (five localities) from 1994 to 2008 (including nine records from the Apache National Forest of Catron County). In 2020, one was captured at Romero Creek in Catron County (NMDGF 2020), but more work on the status and distribution of the montane vole in the Gila is needed.

In November 2014, we failed to find the meadow vole, M. drummondii, at two previously known localities near Aragon in the Gila (recorded in 1915). We also failed to detect the species about $140 \mathrm{~km} \mathrm{~N}$ of the Gila, near San Rafael in Cibola County. Riparian habitat around Aragon is severely over-grazed, reducing the riparian grass-sedge habitat of M. drummondii and potentially causing the local extirpation of this species (Anderson 1961; Anderson and Hubbard 1971; Findley et al. 1975; Jackson and Cook 2020). Southern peripheral populations of this species are genetically distinctive and important components of overall diversity within this species (List et al. 2010; Jackson and Cook 2020). Populations in northern México recently also have been lost due to conflicts with agriculture (List et al. 2010).

Dipodomys spectabilis is listed as Near Threatened by IUCN throughout its range due to loss of desert grassland habitat to encroaching mesquite and creosote (List et al. 2010; Linzey et al. 2013) and a history of federally funded poisoning campaigns. Mitigation of anthropogenic impacts that directly impact kangaroo rats, or lead to shrub encroachment, should be implemented to protect $D$. spectabilis. We captured 11 specimens during the 2012 to 2019 survey at two localities on the Ladder Ranch and saw extensive mounding activity of this species northwest of Winston, New Mexico in 2014. Their mounds are seen along Highway 180 south to Deming and near Faywood in Mimbres Valley.

We include Sciurus arizonensis because of its IUCN Data Deficient status and note that the species is listed as Threatened in México (Coronel-Arellano et al. 2016). Bailey (1931) reported that the Arizona gray squirrel is common along the San Francisco River, and Findley et al. (1975) recounted that it is "limited to the deciduous riparian forest of the San Francisco drainage in Catron Co." However, as Hayward and Hunt (1972) observed, Arizona gray squirrels have been extending their range up the Gila and San Francisco drainages and east towards the Rio Grande. We examined two specimens from 1937 captured near the Sacaton Landing Strip (AMNH M-127032-127033) and one from 1928 captured in the
Mogollon Mountains near Big Dry Creek (AMNH M-127260). Findley et al. (1975) reported that Arizona gray squirrels are usually found in ponderosa pine forest, and Hayward's captures came from low-elevation riparian habitat and piñonjuniper woodland. Hayward also recovered a road-killed Arizona gray squirrel near his home $6 \mathrm{~km}$ north of Silver City in 1985 (WNMU: Mamm: 4781). Frey et al. (2008) reported evidence of range expansion of Arizona gray squirrels eastward into Sierra County of the Gila, including several personal observations, two photographs, and one specimen (MSB: Mamm: 124820) from Sierra County. Camera data from the Ladder Ranch (Figure 8) show Arizona gray squirrels in January, June, July, and September of 2009 providing additional evidence (time-stamped and geo-tagged photographs) of their range extension eastward and persistence. Frey et al. (2008) assert that lack of historic records from the Ladder Ranch belies a range expansion. The distribution of the Arizona gray squirrel in the Gila requires continued monitoring.

Nine other bat species from the Gila (Corynorhinus townsendii, Idionycteris phyllotis, Myotis evotis, M. occultus, $M$. thysanodes, M. velifer, M. volans, M. yumanensis, and Nyctinomops macrotis) are listed on the US Fish and Wildlife Services Bats of Concern List (O'Shea et al. 2018). Some of these are also listed as Species of Concern by the New Mexico Department of Game and Fish. Of these, Myotis evotis was the least common bat encountered in this survey. Idionycteris phyllotis is listed at Imperiled by New Mexico Game and Fish (O'Shea et al. 2018) and was the second least common bat captured in this survey. Corynorhinus townsendii also was among the least often encountered species in mist net surveys in the Gila (O'Shea et al. 2018, this study). A renewed focus on the status of bats of the Gila is needed. In addition to these species, there are a series of other species listed as Data Deficient that should be reviewed. Broad specimen-based surveys, such as conducted here, are the most efficient approach to gather the sampling necessary to stimulate the study of these species.

Habitats of Concern. It is most cost efficient to focus limited conservation and rehabilitation resources on habitats that support multiple threatened species. Increased protection of riparian habitats should be considered a top conservation priority, most importantly along the Mimbres, Gila, and San Francisco rivers and tributaries. More robust exclusion of cattle from these drainages would address the habitat requirements of associated species such as L. blossevillii, M. drummondii, Z. luteus, and S. arizonensis. Over the past five decades, the Gila River in southwestern New Mexico has been proposed for damming and diversion multiple times and efforts will likely continue with a warming and drying climate coupled with increased water demands from major metropolitan areas. The most recent effort to impound the Gila River was rejected by the Interstate Stream Commission in June 2020. Flow variability across different seasons characterizes the Gila River and helps maintain diverse habitat types (riparian forest, wet- 
lands, and floodplains) that elevate mammalian diversity. Proposed diversions would decrease both mid-size flows and negatively impact persistence of riparian forest (e. g., affect roosting sites for bats and habitat for Arizona gray squirrels); lessen the connection of the river to the floodplains (affecting habitat for hydroseric species); diminish aquatic habitat (fish are prey for multiple carnivorous mammals); lower reproduction and emergence of aquatic and aquatic-associated invertebrates (decreased food supply for riparian-associated bats; Fukui 2006; Valdez and O'Shea 2014); and decrease vegetation productivity, potentially important for multiple mammalian species such as the Arizona squirrel, beavers, and muskrats.

Desert-grasslands are in decline regionally. The nearby Jornada Experimental Range found that shrub cover increased by $>12 \%$ and grassland decreased by $>16 \%$ from 1937 to 2003 (Laliberte et al. 2004). Desert-grassland obligate species, like Dipodomys and potentially Onychomys, Chaetodipus, and Perognathus, may be at risk if open grasslands continue to decline. Studies on mammalian population responses to shrub encroachment in the Southwest remain few, but studies elsewhere show dramatic mammalian declines with increased shrub cover (Blaum et al. 2007).

For both riparian and desert-grassland habitats, overgrazing poses a severe threat. The Gila has a long history of heavy grazing pressure, beginning in the late 1880s when cattlemen and sheepherders moved into the area. Shortly thereafter the Stock Raising Homestead Act of 1916 allowed for fencing of grazing allotments and encouraged cattle growers to make water improvements. After the designation of the Gila Wilderness and the Aldo Leopold Wilderness, some of these allotments were reduced and allotments generally decreased from 1928 to 2007 (from 83,499 to $18,772 \mathrm{ha}$ ); however, large numbers of livestock continue to graze on federal lands. Livestock grazing generally decreases biodiversity (Fleischner 2002; Jones 2000; Milchunas and Lauenroth 1993), with especially heavy impacts in riparian zones in the arid Southwest. Hayward et al. (1997) performed small mammal surveys over 10 years at San Simon Cienega in southeastern Arizona (about $90 \mathrm{~km}$ SW of the Gila) and found total abundance of small mammals was about $50 \%$ less in grazed plots, with Sigmodon hispidus and Reithrodontomys megalotis especially sensitive to grazing effects (Hayward et al. 1997). Similarly, Moser and Whitmore (2000) found significantly greater abundance of small mammals, species richness, and diversity on sites that were ungrazed when compared with grazed sites and shrews were only captured on ungrazed sites.

Fire. Fires are a natural part of the ecosystems of the Southwest. Historically, national forests of this region averaged more fires annually than other regions stemming from diverse sources, including one of the largest concentrations of lightning-caused fires worldwide (Pyne 1982). In recent years, however, large catastrophic fires and subsequent flooding have become more common with two of the largest fires in New Mexico's history occurring in the Gila in the last decade (e. g., Whitewater-Baldy in 2012, Silver in 2013). Snowmelt earlier in the spring, increasing temperatures, and high fuel loads due to historic fire suppression have elevated the severity of wildfires in the region (Hurteau et al. 2014). Of particular note for forest and riparian-associated mammal communities is the prediction that many of these forests will not return to prefire forested conditions due to having crossed climatic thresholds for regeneration related to ongoing warming and drought conditions (Davis et al. 2019). Post-fire burned sites of Douglas-fir (Pseudotsuga menziesii) and ponderosa pine (Pinus ponderosa), in particular, have decreased potential to return to their pre-fire forest structure (Haffey et al. 2018; Rodman et al. 2019). Those changes may have negative consequences for a wide variety of both riparianassociated (e. g., Whitney et al. 2015) and forest-associated species of the Gila, such as tree-roosting bats, L. blossevillii, A. cinereus, and L. noctivagans (Kunz 1982; Shump and Shump 1982). Nonetheless, analyses of the impact of fires of different intensities on bat communities in the Sierra Nevadas of California are now revealing the role for forest fires in bat ecology, with some species showing increased occupancy of burned areas (Blakey et al. 2019; Buchalski et al. 2013; Steel et al. 2019). Sciurids, including Sciurus aberti, S. arizonensis, Neotamias cinereicollis, and Tamiasciurus fremonti, also may be impacted by large, catastrophic fires (Koprowski et al. 2006). Tamiasciurus fremonti, for example, has been shown to no longer inhabit areas that have experienced stand-replacing fires (Ream 1981). Although lower intensity fires do not appear to have lasting impact (Blount and Koprowski 2012) on red squirrels in nearby Pinaleño Mountains of southeastern Arizona, the cumulative and synergistic impacts of severe fires, climate warming, drought, insect-invasion and other forest habitat disturbances have resulted in reduced food availability, survival, and reproductive output for this endemic squirrel (Tamiasciurus fremonti grahamensis). Allard-Duchene et al. (2014) reported that $T$. fremonti will inhabit a manually thinned area about 20 years sooner than a burned area. Other studies found that prescribed burns were negatively correlated with occurrence of Neotamias cinereicollis (Converse et al. 2006), but relatively little is known about impacts of these events on biodiversity in the Gila (Whitney et al. 2015).

Climate Change. Although climate variability is natural, recent warming and drying trends in southwestern New Mexico have been accentuated through increased production of $\mathrm{CO}_{2}$ by humans. Data from local weather stations show temperatures in the Gila National Forest, Aldo Leopold National Forest, Ladder Ranch, and surrounding areas have increased while precipitation has decreased since the early 1900s (Girvetz et al. 2009), and these trends have accelerated recently (Jones and Gutzler 2016, O'Connor et al. 2020). Using museum specimens, Moritz et al. (2008), Rubidge et al. (2012), and McCain et al. (2021) have each shown that climate change over the past century can affect the elevational distributions of some mammals. 


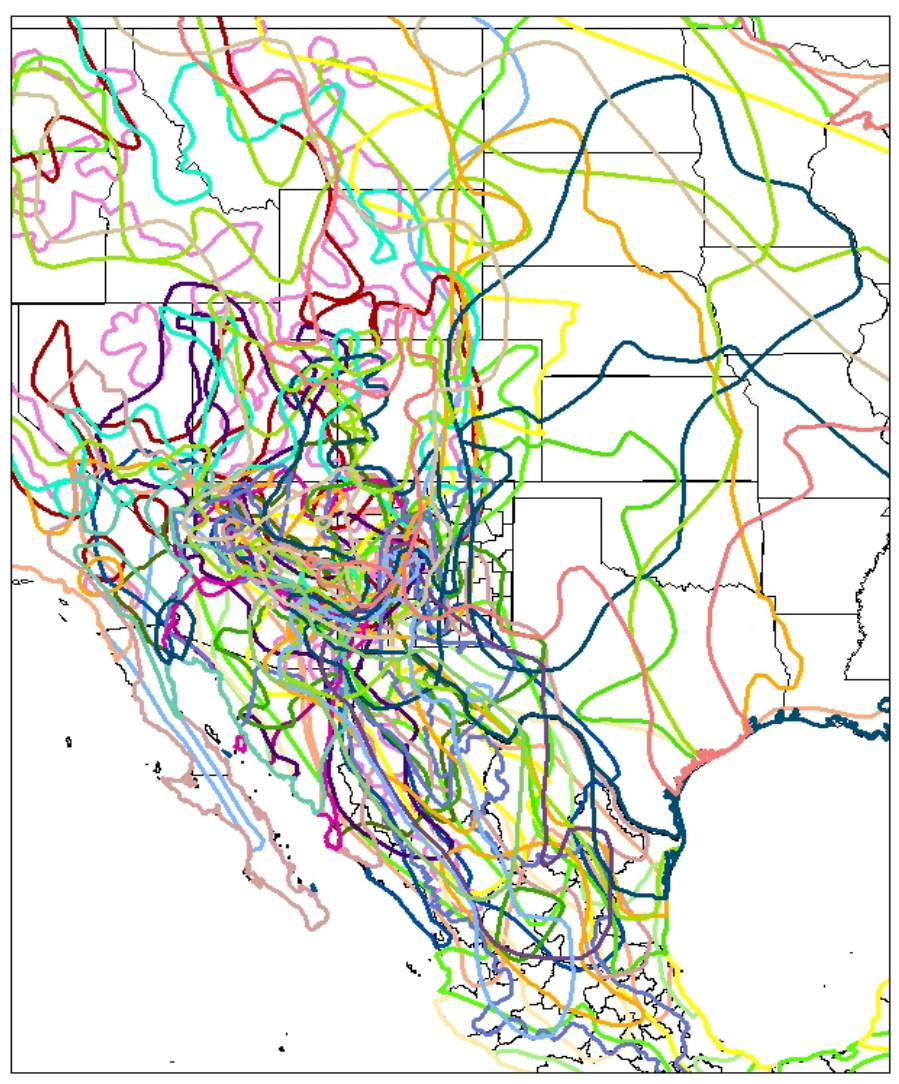

Figure 13. At least 35 species of mammals have their distributional limit in the Gila.

Through the Grinnell Resurvey Project, Moritz et al. (2008) investigated mammalian range shifts in the Sierra Nevada Mountains and generally found that low elevation species expanded their ranges upslope, while the ranges of higher elevation montane species contracted. Some species showed idiosyncratic movements, hypothetically due to competitive release when congeners were displaced. Similarly, we hypothesize potential range shifts of species along elevational gradients in the Gila Region with possible range expansion of lower elevation desert, grassland, and woodland-associated species and range contraction in montane and riparian species. Such changes may increase the risk of extirpation of high-elevation species as their ranges decline (McDonald and Brown 1992; Parmesan 2006).

Bats are also at risk due to disrupted climate regimes. Adams (2010) showed a significant decrease in reproduction of insectivorous bats in years with lower precipitation in the Front Range of Colorado. Rebelo et al. (2010) hypothesized that many bat species will be at risk of extinction due to rising temperatures and declining precipitation; thus, some populations in the Gila may be locally extirpated in the future with increasing drought conditions. Several New Mexico bat species roost communally, where dehydration presents significant challenges due to the high temperature and low humidity of the microclimates within roosts. Communal maternity roosts may be challenged by the increased physiological stress on nursing mothers due to milk production (Adams 2008). Therefore, the ability of female bats to survive and raise young hinges on readily accessible open water. Given projected trends for warming and drying across the Southwest, reproductive success of bats in New Mexico may be severely reduced. Sherwin et al. (2012) reviewed potential risk factors for bats with changing climate and classified food, roosts, reproduction, and distribution as potential risks. Reduced precipitation may decrease food availability for insectivorous and frugivorous bats. Habitat availability also may be decreased for treeroosting bats. In addition, problems associated with ability to reproduce as outlined by Adams $(2008,2010)$ are likely, and species with small ranges or higher elevation associations may be differentially affected by dramatic environmental warming and aridification (Sherwin et al. 2012). As most bat species migrate or hibernate, their phenology should be carefully monitored in relation to climate trends to understand whether they are impacted. Georeferenced specimens not only unequivocally document the time and place of species occurrence, but they also can provide insights into physiological status related to hibernation, migration, and reproduction.

Specimen-based research. The lack of repeated faunal surveys documented by holistic specimens continues to hamper the study of Gila biodiversity, suggesting an urgent need to build natural history collections, which can serve as primary infrastructure or libraries of biodiversity for the region (Malaney and Cook 2018). Natural history specimens not only provide the necessary retrospective materials (i. e., historical baselines; Suarez and Tsutsui 2004; McLean et al. 2016; Cook and Light 2019) to understand how changing conditions are impacting organisms, but they also provide a foundation for forecasting how future changing conditions may impact aspects of biodiversity (Schindel and Cook 2018; Funk 2018). Recent evolution of the concept of voucher specimens has resulted in collections of holistic specimens that include traditional vouchers (e. g., fluid, skin and skeleton) that are now associated with diverse ancillary materials (e. g., multiple ultra frozen tissues), and preserved endoparasites and ectoparasites (Dunnum and Cook 2012; Galbreath et al. 2019). Parasitism plays a large role in structuring biotic communities, yet this aspect of mammalian biology has been minimally evaluated throughout the Southwest. Parasites can also yield historical and biogeographic insights not revealed by examination of host-history alone (Galbreath et al. 2020). Holistic collections of mammals, such as exemplified in this study, provide a sampling infrastructure that will facilitate integrated insights into the history and future trajectory of natural communities (Gardner and Campbell 1992; Galbreath and Hoberg 2015; Brooks et al. 2019). This broad array of material allows for more intensive and integrated investigations of the biology of these organisms (Dunnum et al. 2020), taking advantage of recent advances in technology (e. g., genomics, stable isotopes, microCT scans), analyses (e. g., ecological niche modeling; Cook and Light 2019), and immediate on-line access to these ever-growing data 
streams through vast data repositories (e. g., GenBank, IsoBank, MorphoBank).

Our ability to investigate and more completely understand aspects of these complex systems, including the impact of changing environmental conditions in the future, will primarily be limited by the extent of the sampling that we preserve now for future generations of scientists, managers, planners, policy makers, and educators (Malaney and Cook 2018). With regard to educators, biological collections that are accessible on-line have proven to be novel resources for K-16 educators and citizen scientists to more deeply learn about the natural world (Powers et al. 2014; National Academies of Sciences, Engineering, and Medicine 2020). When associated with active research programs at academic institutions, collections have long been key to the development of the next generation of naturalists (Cook et al. 2014, 2016; Lacey et al. 2017). Educators can draw on the rich biodiversity datasets now available for the Gila, and through specimen-based activities students can learn how to integrate across disciplines as they are drawn into a diverse and growing network of scientists that are producing fascinating insights into biology, chemistry, public health, and an array of other fields (Schmidly 2001, 2005).

We recognize that a key finding emerging from this overview of taxonomy, distribution, phylogeographic history, and conservation concerns for Gila mammals is that our understanding of this fauna remains incomplete. By emphasizing information principally backed by specimens, there is now a durable sampling platform that will stimulate future integrative studies (e. g., Cook et al. 2017; Funk 2018; Thompson et al. 2021), investigations that will substantially extend these preliminary results as they unravel the complex role of mammals and their symbionts in Gila ecosystem dynamics.

\section{Acknowledgments}

We first thank Dave Schmidly for his help in the field, scientific guidance, editorial skills, and for paving the way for future mammalogists, including the employment of AKJ during her master's thesis. We thank Steve Dobrott for his professional insights on wildlife management in the Gila and he and his staff for assistance on the project and access to the Ladder Ranch. We thank Dan Warren for his tireless efforts to capture shrews, take detailed notes on mammals, and photograph wildlife. We thank Stephen O. MacDonald, David J. Hafner, Dan Warren, Harley Shaw, Ernie Valdez, and an anonymous individual for reviewing the manuscript and providing helpful observations and information. Jeff Lehmer provided information and materials related to furbearers. We thank Marjorie McConnell, Robert Nofchissey, Mariel Campbell, Kayce Bell, Bryan McLean, Katrina Derieg, Danielle Parsons, and many other UNM students for their help and expertise in the field. Curatorial staff at the National Museum of Natural History, American Museum of Natural History, and Western New Mexico University Museum graciously provided access to their mammal collections. Fieldwork was partially supported by grants from the College of Arts of Sciences at the University of New Mexico and the Museum of Southwestern Biology Mammal Fund.

\section{Literature Cited}

Adams, R. A. And M. A. Hayes. 2008. Water availability and successful lactation by bats as related to climate change in arid regions of western North America. Journal of Animal Ecology 77:1115-1121.

Adams, R. A. 2010. Bat reproduction declines when conditions mimic climate change projections for western North America. Ecology 91:2437-2445.

Allard-Duchêne, A., D. Pothier, A. Dupuch, and D. Fortin. 2014. Temporal changes in habitat use by snowshoe hares and red squirrels during post-fire and post-logging forest succession. Forest Ecology and Management 313:17-25.

Ammerman, L. K., C. L. Hice, and D. J. Schmidly. 2012. Bats of Texas. Texas A\&M University Press. College Station, U.S.A.

Anderson, S. 1961. A relict population of Microtus pennsylvanicus in southwestern New Mexico. American Museum Novitates 2034:1-3.

Anderson, S., AND J. P. Hubbard. 1971. Notes on geographic variation of Microtus pennsylvanicus (Mammalia, Rodentia) in New Mexico and Chihuahua. American Museum Novitates 2460:1-8.

Andersen, J. J., AND J. E. Light. 2012. Phylogeography and subspecies revision of the hispid pocket mouse, Chaetodipus hispidus (Rodentia: Heteromyidae). Journal of Mammalogy 93:1195-1215.

Balley, V. 1931. Mammals of New Mexico. U.S. Government Printing Office No. 53-57.

Blakey, R. V., E. B. Webb, D. C. Kesler, R. B. Siegel, D. Corcoran, AND M. Johnson. 2019. Bats in a changing landscape: Linking occupancy and traits of a diverse montane bat community to fire regime. Ecology and Evolution 9:5324-5337.

Blaum, N., E. Rossmanith, A. Popp, and F. Jeltsch. 2007. Shrub encroachment affects mammalian carnivore abundance and species richness in semiarid rangelands. Acta Oecologica 31:86-92.

Blount, S. J. AND J. L. Koprowski. 2012. Response of the Mount Graham Red Squirrel (Tamiasciurus hudsonicus grahamensis) to Postfire Conditions. The Southwestern Naturalist 57: 8-15.

Bogan, M. A., P. M. Cryan, C. D. Weise, and E. W. Valdez. 2017. Landscape movements by two species of migratory nectarfeeding bats (Leptonycteris) in a northern area of seasonal sympatry. Western North American Naturalist 77:317-330.

Bradley, R. D., AND M. R. Mauldin. 2016. Molecular data indicate a cryptic species in Neotoma albigula (Cricetidae: Neotominae) from northwestern México. Journal of Mammalogy 97:187-199.

Brooks, D. R. , E. P. Hoberg, and W. A. Boeger. 2019. The Stockholm Paradigm: Climate change and emerging disease. University of Chicago Press. Chicago, U.S.A.

Buchalski, M. R., J.B. Fontaine, P. A. Heady, J. P. Hayes and W. F. FrICK. 2013. Bat response to differing fire severity in mixedconifer forest California. Plos One 8: e57884.

Conroy, C. J., AND J. A. Cook. 2000. Phylogeography of a postglacial colonizer, Microtus longicaudus (Muridae: Rodentia). Molecular Ecology 9:165-175. 
Converse, S. J., W. M. Block, And G. C. White. 2006. Small mammal population and habitat responses to forest thinning and prescribed fire. Forest Ecology and Management 228:263-273.

Cook, J. A. 1986. The Mammals of the Animas Mountains. Occasional Papers of The Museum of Southwestern Biology 4:1-45.

Cook, J. A., S. V. Edwards, E. A. Lacey, R. P. Guralnick, P. S. Soltis, D. E. Soltis, C. K. Welch, K. C. Bell, K. E. Galbreath, C. Himes, AND J. M. Allen. 2014. Natural history collections as emerging resources for innovative education. BioScience 64:725-734.

Cook, J. A., K. Galbreath, K. Bell, M. Campbell, S. Carrière, J. P Colella, N. G Dawson, J. L Dunnum, R. P Eckerlin, S. E Greiman, V. Fedorov, G. M. S. Haas, V. Haukisalmi, H. Henttonen, A. G Hope, D. Jackson, T. Jung, A. V Koehler, J. M Kinsella, D. Kresja, S. J Kutz, S.r Liphardt, S. O MacDonald, J. L Malaney, A. Makarikov, J. Martin, B. S McLean, R. Mulders, B. Nyamsuren, S. L Talbot, V. TKach, A. Tsvetkova, H. Toman, E. C Waltarl, J. S Whitman, AND E. P Hoberg. 2017. Arctic Museum Collections-Special Issue. The Beringian Coevolution Project: Holistic collections of mammals and associated parasites reveal novel perspectives on evolutionary and environmental change in the North. Arctic Science 3:585-617.

Cook, J. A., S. Greiman, S. Agosta, R. P. Anderson, B. S. Arbogast, R. J. Baker, W. Boeger, R. D. Bradley, D. R. Brooks, R. Cole, J. R. Demboski, A. P. Dobson, J. L. Dunnum, R. P. Eckerlin, J. Esselstyn, K. Galbreath, J. Hawdon, H. Hoekstra, S. Kutz, J. Light, L. Olson, B. D. Patterson, J. L. Patton, A. J. Phillips, E. Rickart, D. S. Rogers, M. Siddall, V. TKach, and E. P. Hoberg. 2016. Transformational principles for NEON sampling of mammalian parasites and pathogens: a response to Springer and colleagues. BioScience 66: 917-919.

Cook, J.A., E. A. LACEY, S. M. ICKeRT-Bond, E. P. Hoberg, K. E. GaLbreath, K. C. Bell, S. E. Greiman, B. S. McLean, and S. V. Edwards. 2016. From Museum Cases to the Classroom: Emerging Opportunities for Specimen-Based Education. Pp 787-799, in Aspects of Biodiversity (Pavlinov, I., ed.). Archives of Zoological Museum of Moscow State University, Moscow, Russia.

COOK, J. A., AND J. E. LIGHT. 2019. The emerging role of mammal collections in $21^{\text {st }}$ Century mammalogy. Journal of Mammalogy 100:733-750.

Coronel-Arellano, H., N. E. Lara-Diaz, R. E. Jiménez-Maldonado, and C. A. López-González. 2016. Species richness and conservation status of medium and large terrestrial mammals from four Sky Islands in Sonora, northwestern Mexico. Check List 12:1839.

Cosgrove, C. B. 1947. Caves of the Upper Gila and Hueco areas in New Mexico and Texas. Papers of the Peabody Museum of American Archaeology and Ethnology, Harvard University 24:1-182.

Crawford, D. L., J. W. Dragoo, F. A. Smith, and A. N. Chavez. 2011. Diversification within the Mexican vole (Microtus mexicanus) and the role of post-Pleistocene climate change. Western North American Naturalist 71:176-194.

Davis, K. T., S. Z. Dobrowski, P. E. Higuera, Z. A. Holden, T. T. Veblen, M. T. Rother, S. A. Parks, A. Sala, and M. P. Maneta. 2019. Wildfires and climate change push low-elevation forests across a critical climate threshold for tree regeneration. Proceedings of the National Academy of Sciences 116:6193-6198.
Derieg, K. M., K. GuitiérRez, S. W. Liphardt, J. L. Malaney, and J. A. Соoк. 2021. Mitonuclear discordance in woodrats (Genus Neotoma) points to historical mitochondrial introgression. submitted.

Dick-Peddie, D., W. A. Moir, W. H. Moir and R. Spellenberg. 1993. New Mexico vegetation: past, present, and future. University of New Mexico Press. Albuquerque, U.S.A.

Dragoo, J. W., J. A. Lackey, K. E. Moore, E. P. Lessa, J. A. Cook, and T. L. Yates. 2006. Phylogeography of the deer mouse (Peromyscus maniculatus) provides a predictive framework for research on hantaviruses. Journal of General Virology 87:1997-2003.

Dunnum, J. L., AND J. A. Cook. 2012. Gerrit Smith Miller: his influence on the enduring legacy of natural history collections. Mammalia 76:365-373.

Dunnum, J. L., J. L. Malaney, and J. A. Соoк. 2020. Syd's Legacy: Sustained impact of holistic specimens for mammalogy and parasitology in South America. Therya 11:347-358.

Duran, K. L., A. Pardo, and J. B. Melton. 2012. From middens to molecules: phylogeography of the pinon pine, Pinus edulis. Journal of Biogeography 39:1536-1544.

Edwards, C. W., C. F. Fulhorst, and R. D. Bradley. 2001. Molecular phylogenetics of the Neotoma albigula species group: further evidence of a paraphyletic assemblage. Journal of Mammalogy 82:267-279.

FinDLeY, J.S. 1969. Biogeography of southwestern boreal and desert mammals. University of Kansas Museum of Natural History Miscellaneous Publication 51:1-13.

Findley, J. S., A. H. HarRis, D. E. Wilson, ANd C. Jones. 1975. Mammals of New Mexico. University of New Mexico Press. Albuquerque, U.S.A.

FLEISCHNER, T.L. 2002. Land held hostage: a history of livestock and politics. Welfare ranching: the subsidized destruction of the American West 33-38.

Fleming, M. A., AND J. A. Cook. 2002. Phylogeography of endemic ermine (Mustela erminea) in southeast Alaska. Molecular Ecology 11:795-808.

Frey, J. K., M. T. Hill, B. L. Christman, J. C. Truett, and S. O. MACDonald. 2008. Distribution and habitat of the Arizona gray squirrel (Sciurus arizonensis) in New Mexico. The Southwestern Naturalist 53:248-255.

Frey, J. K. 2010. Mammals of the Gila: patterns of diversity and threat. Proceedings of the Second Natural History of the Gila Symposium, October 2008. New Mexico Botanist 2:67-87.

Fukul, D. A. I., M. Murakami, S. Nakano, and T. Aol. 2006. Effect of emergent aquatic insects on bat foraging in a riparian forest. Journal of Animal Ecology 75:1252-1258.

Funk, V. A. 2018. Collections-based science in the $21^{\text {st }}$ Century. Journal of Systematics and Evolution 56:175-193.

Galbreath, K. E., and E. P. Hoberg. 2015. Host responses to cycles of climate change shape parasite diversity across North America's Intermountain West. Journal of Vertebrate Biology 64:218-232.

Galbreath, K. E., E. P. Hoberg, J. A. Cook, B. Armién, K. C. Bell, M. L. Campbell, J. L. Dunnum, A. T. Dursahinhan, R. P. Eckerlin, S. L. Gardner, S. E. Greiman, H. Henttonen, F. A. Jiménez, A. V. A. Koemler, B. Nyamsuren, V. V. TKach, F. Torres-Pérez, A. TsvetKova, AND A. G. Hope. 2019. Building an integrated in- 
frastructure for exploring biodiversity: field collections and archives of mammals and parasites. Journal of Mammalogy 100: 382-393.

Galbreath, K. E., H. M. Toman, C. LI, and E. P. Hoberg. 2020. When parasites persist: tapeworms survive host extinction and reveal waves of dispersal across Beringia. Proceedings of the Royal Society B 287:doi.org10.1098/ rspb.2020.1895.

Gardner, S. L., AND M.L. Campbell. 1992. Parasites as probes for biodiversity. Journal of Parasitology 78:596-600.

Geluso, K. 2007. Winter activity of bats over water and along flyways in New Mexico. The Southwestern Naturalist 52:482-492.

Geluso, K. 2017. Recurrence of spotted bats (Euderma maculatum) at historical sites in New Mexico, with notes on natural history. Occasional Papers, Museum of Texas Tech University 346:1-14.

Geluso, K. N. AND K. Geluso. 2020. Distribution and natural history of the Yellow-nosed Cotton Rat (Sigmodon ochrognathus) in southwestern New Mexico. Occasional Papers, Museum of Texas Tech University 362:1-21.

Girvetz, E. H., C. Zganjar, G. T. Raber, E. P. Maurer, P. Kareiva, AND J. J. Lawler. 2009. Applied climate-change analysis: the climate wizard tool. PLoS One 4:8320.

Haffey, C., T. D. Sisk, C. D. Allen, A. E. Thode, and E. Q. MargoLIS. 2018. Limits to Ponderosa Pine Regeneration following Large High-Severity Forest Fires in the United States Southwest. Fire Ecology 14:143-163.

Hafner, D. J., J. C. Hafner, and M. S. Hafner. 1984. Skin plus skeleton preparation as the standard mammalian museum specimen. Curator 27:141-145.

Hayward, B. J., AND D. L. Hunt, JR. 1972. Vertebrate survey of the Wilderness Ranger District, Gila National Forest, New Mexico. U.S. Department of Agriculture, Forest Service Technical Report. Silver City, New Mexico.

Hayward, B. J., E. J. Heske, and C. W. Painter. 1997. Effects of livestock grazing on small mammals at a desert cienega. The Journal of Wildlife Management 61:123-129.

Hedrick, P. W., ANd R. J. Fredrickson. 2008. Captive breeding and the reintroduction of Mexican and red wolves. Molecular Ecology 17:344-350.

Hibitts, T. J., C. W. Painter, and A. T. Holycross. 2009. Ecology of a population of the narrow-headed gartersnake (Thamnophis rufipunctatus) in New Mexico: catastrophic decline of a river specialist. Southwestern Naturalist 54:461-467.

Hoffmelster, D. F. 1986. Mammals of Arizona. University of Arizona Press. Tucson, U.S.A.

Hoffmeister, D. F. ANd M. R. LeE. 1986. Taxonomic review of cottontails, Sylvilagus floridanus and Sylvilagus nuttallii, in Arizona. American Midland Naturalist 70:138-148.

Hope, A. G., E. Waltari, N. E. Dokuchaev, S. Abramov, T. Dupal, A. Tsvetkova, H. Henttonen, S. O. MacDonald, and J. A. Cook. 2010. High-latitude diversification within Eurasian least shrews and Alaska tiny shrews (Soricidae). Journal of Mammalogy 91:1041-1057.

Hope, A. G., J. L. Malaney, K. C. Bell, F. Salazar-Miralles, A. S. Chavez, B. R. Barber, and J. A. Cook. 2016. Revision of widespread red squirrels (genus: Tamiasciurus) highlights the complexity of speciation within North American forests. Molecular phylogenetics and evolution 100:170-182.
Hurteau, M. D., J. B. Bradford, P. Z. Fulé, A. H. Taylor, and K. L. MARTIN. 2014. Climate change, fire management, and ecological services in the southwestern US. Forest Ecology and Management 327:280-289.

Hoyt, R. A., J. S. AltenbaCh, and D. J. Hafner. 1994. Observations on long-nosed bats (Leptonycteris) in New Mexico. The Southwestern Naturalist 39:175-179.

JACKson, D. J., AND J. A. Cook. 2020. A precarious future for distinctive peripheral populations of meadow voles (Microtus pennsy/vanicus). Journal of Mammalogy 101:36-51.

Jezkova, T., J. R. Jaeger, Z. L. Marshall, ANd B. R. Riddle. 2009. Pleistocene impacts on the phylogeography of the desert pocket mouse (Chaetodipus penicillatus). Journal of Mammalogy 90:306-320.

Jones, A. 2000. Effects of cattle grazing on North American arid ecosystems: a quantitative review. Western North American Naturalist 60:155-164.

JoNes, C. 1965. Ecological distribution and activity periods of bats of the Mogollon Mountains area of New Mexico and adjacent Arizona. Tulane Studies in Zoology 12:93-100.

Jones, S. M., AND D. M. GutzLer. 2016 Spatial and seasonal variations in aridification across Southwest North America. Journal of Climate 29:4637-4649.

Julyan, R. 2006. The Mountains of New Mexico. University of New Mexico Press. Albuquerque, U.S.A.

Koprowski, J. L., K. M. Leonard, C. A. Zugmeyer, and J. L. Jolley. 2006. Direct Effects of Fire on Endangered Mount Graham Red Squirrels. The Southwestern Naturalist 51: 59-63.

Kunz, T. H. 1982. Roosting ecology of bats. Pp. 1-55, in Ecology of bats (Kunz, T.H., ed.) Platinum Publishing Corporation. New York, U.S.A.

Kunz, T. H., And S. Parsons (eds.). 2009. Ecological and Behavioral Methods for the Study of Bats, 2nd. Ed. Johns Hopkins University Press. Baltimore, U.S.A.

Lacey, E. A., T. T. Hammond, A. Mast, R. P. Guralnick, A. Monfils, J. McCormack, L. ElLwood, P. Soltis, D. Soltis, K. BelL, S. M. ICKERT-Bond, S. V. Edwards, AND J. A. Cook. 2017. Climate Change, Collections and the Classroom: Using Big Data to Tackle Big Problems. Evolution: Education \& Outreach 10:1-13.

Laliberte, A. S., A. Rango, K. M. Havstad, J. F. Paris, R. F. Beck, R. McNeely, AND A. L. Gonzalez. 2004. Object-oriented image analysis for mapping shrub encroachment from 1937 to 2003 in southern New Mexico. Remote Sensing of Environment 93:198-210.

Lamb, T., T. R. Jones, and P. J. Wettstein. 1997. Evolutionary genetics and phylogeography of tassel-eared squirrels (Sciurus aberti). Journal of Mammalogy 78:117-133.

Linzey, A. V., R. Timm, S. T. Álvarez-Castañeda, J. K. Frey, and T. LACHER. 2013. Dipodomys spectabilis. In: IUCN Red List of Threatened Species. Version 2013.1

List, R., O. R. Pergams, J. Pacheco, J. Cruzado, and G. Ceballos. 2010. Genetic divergence of Microtus pennsylvanicus chihuahuensis and conservation implications of marginal population extinctions. Journal of Mammalogy 91:1093-1101.

MacDonald, S. O., AND J. A. Cook. 2007. Mammals and amphibians of Southeast Alaska. Special Publication, the Museum of Southwestern Biology 8:1-193.

Malaney, J. L., J. K. Frey, and J. A. Сook. 2012. The biogeographic legacy of an imperiled taxon provides a foun- 
dation for assessing lineage diversification, demography and conservation genetics. Diversity and Distributions 18:689-703.

Malaney, J., AND J. A. Cook. 2018. A perfect storm for mammalogy: declining sample availability in a period of rapid environmental degradation. Journal of Mammalogy 99:773-788.

Malaney, J. L., J. L. Dunnum, and J. A. Cook. 2021. Updated checklist of New Mexico Mammals. New Mexico Museum of Natural History and Science Bulletin. In press.

Malaney, J L., C. R. Wilford, J. Woods, B. L. Christman, R. D. Jennings, C. L. Chambers, J. L. Zahratka, S. W. Liphardt, and J. A. Cоoк. Wagering with an incomplete deck - refining the predictive basis for future conservation plans for endangered jumping mice (Zapus luteus). Submitted.

McCain, E. B., AND J. L. Childs. 2008. Evidence of resident jaguars (Panthera onca) in the southwestern United States and the implications for conservation. Journal of Mammalogy 89:1-10.

McCain, C. M., S. R. KInG, AND T. M. SzewczYk. 2021. Unusually large upward shifts in cold-adapted montane mammals as temperature warms. Ecology, p.e03300

McDonald, K. A., AND J. H. Brown. 1992. Using montane mammals to model extinctions due to global change. Conservation Biology 6:409-415.

Mclean, B. S., K. C. Bell, J. L. Dunnum, B. Abrahamson, J. P. Colella, E. R. Deardorff, J. A. Weber, A. K. Jones, F. SalazarMiralles, AND J. A. Cook. 2016. Natural history collectionsbased research: progress, promise, and best practices. Journal of Mammalogy 97:287-297.

Milchunas, D. G., and W. K. Lauenroth. 1993. Quantitative effects of grazing on vegetation and soils over a global range of environments. Ecological Monographs 63:327-366.

Moritz, C., J. L. Patton, C. J. Conroy, J. L. Parra, G. C. White, and S. R. BeISSINGER. 2008. Impact of a century of climate change on small-mammal communities in Yosemite National Park, U.S.A. Science 322:261-264.

Morgan, G. S., P. L. Sealey, and S. G. Lucas. 2011. Pliocene and early Pleistocene (Blancan) vertebrates from the Palomas Formation in the vicinity of Elephant Butte Lake and Caballo Lake, Sierra County, southwestern New Mexico. New Mexico Museum of Natural History and Science Bulletin 53:664-736.

Morgan, G. S. 2015. Late Cenozoic vertebrate faunas from the Gila region of Southwestern New Mexico. Proceedings of the Fourth Natural History of the Gila Symposium, October 2012. The New Mexico Botanist 4:77-105.

Moser, B. W., AND G. W. Whitmore. 2000. The effect of cattle and elk foraging on the vegetation, birds, and small mammals of the Bridge Creek Wildlife Area, Oregon. International Biodeterioration and Biodegradation 45:151-157.

National Academies of Sciences, Engineering, and Medicine. 2019. Evaluating the Taxonomic Status of the Mexican Gray Wolf and Red Wolf. Washington, D.C.: The National Academies Press. https://doi.org/10.17226/253512. Accessed April 16, 2019.

National Academies of Sciences, Engineering, and Medicine. 2020. Biological Collections: Ensuring Critical Research and Education for the 21st Century. Washington, DC: The National Academies Press. https://doi.org/10.17226/25592. Accessed August 20, 2020.
Neiswenter, S. A., And B. R. Riddle. 2010. Diversification of the Perognathus flavus species group in emerging arid grasslands of western North America. Journal of Mammalogy 91:348-362.

New Mexico Department of Game and Fish. 2020. 2020 Biennial review of Threatened and Endangered species of NM, draft. https://www.wildlife.state.nm.us/download/department/ public-comment/biennial/2020-Biennial-Review-Draft.pdf. Accessed December 12, 2020.

O'Connor, C. D., D. A. Falk and G. M. Garfin. 2020. Projected climate-fire interactions drive forest to shrubland transition on an Arizona Sky Island. Frontiers Environmental Sciences 8:137. O'Shea, T. J., P. M. Cryan, ANd M. A. Bogan. United States bat species of concern: A synthesis. Proceedings of the California Academy of Sciences 65:1-279.

Parmesan, C. 2006. Ecological and evolutionary responses to recent climate change. Annual Review of Ecology, Evolution, and Systematics 37:637-669.

Patterson, B. D. 1980. Montane mammalian biogeography in New Mexico. The Southwestern Naturalist 25:33-40.

Patton, J. L., AND M. F. Smith. 1990. The evolutionary dynamics of the pocket gopher Thomomys bottae, with emphasis on California populations. University of California, Berkeley, Publications in Zoology 123:1-161.

Powers, K. E., L. A. Prather, J. A. Cook, J. Woolley, H. L. Bart JR., A. K. Monfils, And P. Sierwald. 2014. Revolutionizing the use of natural history collections in education. The Science Education Review 13: 24-33.

Propst, D. L., T. F. Turner, J. A. Monzingo, J. E. Brooks, AND D. J. Myers. 2020. Ecology, politics, and conservation of Gila trout. Pp. 295-316, in Standing Between Life and Extinction (Propst, D. L., J. E. Williams, K. R. Bestgen, and C. W. Hoagstrom, eds.). University of Chicago Press, Chicago, Illinois, U.S.A.

Pyne, S. J. 1982. Fire in America. A cultural history of wildland and rural fire. Princeton University Press. Princeton, New Jersey, U.S.A.

Rambaut A. 2014. Figtree, a graphical viewer of phylogenetic trees. Available from: https://tree.bio.ed.ac.uk/software/figtree.

Ream, C. H. 1981. The effects of fire and other disturbances on small mammals and their predators: an annotated bibliography. US Department of Agriculture, Forest Service, Intermountain Forest and Range Experiment Station. General Technical Report INT 106:1-55.

Rebelo, H., P. Tarroso, and G. Jones. 2010. Predicted impact of climate change on European bats in relation to their biogeographic patterns. Global Change Biology 16:561-576.

Reding, D. M., A. M. Bronikowski, W. E. Johnson, and W. R. Clark. 2012. Pleistocene and ecological effects on continental-scale genetic differentiation in the bobcat (Lynx rufus). Molecular Ecology 21:3078-3093.

RIDDLE, B. R. 1995. Molecular biogeography in the pocket mice (Perognathus and Chaetodipus) and grasshopper mice (Onychomys): the late Cenozoic development of a North American aridlands rodent guild. Journal of Mammalogy 76:283-301.

Riddle, B. R., D. J. Hafner, and L. F. Alexander. 2000. Phylogeography and systematics of the Peromyscus eremicus species group and the historical biogeography of North American warm regional deserts. Molecular Phylogenetics and Evolution 17:145-160. 
Ridde, B. R., ANd D. J. Hafner. 2006. A step-wise approach to integrating phylogeographic and phylogenetic biogeographic perspectives on the history of a core North American warm deserts biota. Journal of Arid Environments 66: 435-461.

Robinson, M.J. 2005. Prospects for Mexican gray wolf recovery on the Sky Islands. Pp. 341-344 in: Connecting mountain islands and desert seas: biodiversity and management of the Madrean Archipelago II. USDA Forest Service Proceedings RMRS-P-36. Fort Collins, Colorado, U.S.A.

Rodman, K. C., T. T. Veblen, M. A. Battaglia, M. E. Chambers, P. J. Fornwalt, Z. A. Holden, T. E. Kolb, J. R. Ouzts, and M. T. RothER. 2020. A changing climate is snuffing out post-fire recovery in montane forests. Global Ecology and Biogeography 29:2039-2051.

Ronquist, J. P., And J. P. Huelsenbeck. 2003. MRBAYES 3: Bayesian phylogenetic inference under mixed models. Bioinformatics 19:1572-1574.

RuedAs, L. A. 1998. Systematics of Sylvilagus Gray, 1867 (Lagomorpha: Leporidae) from southwestern North America. Journal of Mammalogy 79:1355-1378.

Rubidge, E. M., J. L Patton, M. A. Lim, A. C. Burton, J. S. Brashares, And C. Moritz. 2012. Climate-induced range contraction drives genetic erosion in an alpine mammal. Nature Climate Change 2:285-288.

Sanderson, E. W., K. Fisher, R. Peters, J. P. Beckmann, B. Bird, C. M. Bradley, J. C. Bravo, M. M. Grigione, J. R. Hatten, C. A. Lopez González, K. Menke, J. R. B. Miller, P. S. Miller, C. Mormorunni, M. J. Robinson, R. E. Thomas, And S. Wilcox. 2021. A systematic review of potential habitat suitability for the jaguar Panthera onca in central Arizona and New Mexico, U.S.A. Oryx: 1-12.

Schindel, D. E., AND J. A. Cook. 2018. The next generation of natural history collections. PLoS Biology 16: e2006125.

Schmidly, D. J. 2001. Universities and natural history museums in the twenty-first century: opportunities for excellence and engagement. Pp. 35-46, in A university natural history museum for the new millenium (Mares, M.A., ed.). Sam Noble Oklahoma Museum of Natural History, University of Oklahoma. Norman, U.S.A.

Schmidly, D. J. 2005. What it means to be a naturalist and the future of natural history at American universities. Journal of Mammalogy 86:449-456.

Schollmeyer, K. G., AND S. O. MacDonald. 2020. Faunal remains from archaeology sites in southwestern New Mexico. Occasional Papers of the Museum of Southwestern Biology 13:1-58.

Sherwin, H. A., W. I. Montgomery, And M. G. Lundy. 2012. The impact and implications of climate change for bats. Mammal Review 43:171-182.

Shump, K. A., ANd A. U. Shump. 1982. Lasiurus cinereus. Mammalian Species 185:1-5.

Sikes, R. S. and the Animal Care and Use Committee of the American Society of Mammalogists. 2016. 2016 guidelines of the American Society of Mammalogists for the use of wild mammals in research and education. Journal of Mammalogy 97:663-673.

Simpson, G. G. 1945. The principles of classification and a classification of mammals. Bulletin, American Museum of Natural History 85:1-350.

Smith, M. F., And J. L. Patton. 1988. Subspecies of pocket gophers: causal bases for geographic differentiation in Thomomys bottae. Systematic Biology 37:163-178.
Stearns, C. E. 1942. A fossil marmot from New Mexico and its climatic significance. American Journal Science 240:867-878.

Steel, Z. L., B. Campos, W. F. Frick, R. Burnett, and H. D. Safford. 2019. The effects of wildfire severity and pyrodiversity on bat occupancy and diversity in fire-suppressed forests. Scientific Reports 9:16300.

Suarez, A. V., AND N. D. Tsutsul. 2004. The value of museum collections for research and society. BioScience 54:66-74.

Sullivan, J., J. R. Demboskı, K. C. Bell, S. Hird, B. Sarver, N. Reid, AND J. M. Good. 2014. Divergence with gene flow within the recent chipmunk radiation (Tamias). Heredity 113:185-194.

Thompson, C., K. Phelps, M. Allard, J. Cook, J. Dunnum, A. Ferguson, M. Gelang, F. Ali Awarali Khan, D. Paul, D. Reeder, N. Simmons, M. Vanhove, P. Webala, M. Weksler, and C. W. Kilpatrick. 2021. Preserve a Voucher Specimen! The critical need for integrating natural history collections in infectious disease studies. mBio 12:e02698-20.

U.S. Fish and Wildiffe Service. 1994. Endangered and threatened wildlife and plants; proposed endangered status for the jaguar in the United States. Federal Register 59:35674-35679.

U. S. Fish and Wildifife Service. 2010. Mexican wolf conservation assessment. https://www.fws.gov/southwest/es/mexicanwolf/pdf/mexican wolf conservation assessment.pdf. Accessed March 10, 2016.

U.S. Fish and Wildife Service. 2015. Endangered and Threatened Wildlife and Plants; Revision to the Regulations for the Nonessential Experimental Population of the Mexican Wolf: Federal Register 80: 2488-2567.

U.S. Fish and Wildife Service News Release. 2016. The 2015 Mexican wolf population survey reveals more work to be done but strategy remains viable. https://www.fws.gov/ southwest/es/mexicanwolf/pdf/NR 2015 MW Annual Survey.pdf. Accessed March 1, 2016.

U. S. Fish and Wildife Service. 2017. Mexican Wolf Recovery Plan, First Revision. Region 2, Albuquerque, U.S.A.

U.S. Fish and Wildife Service. 2018. Jaguar Recovery Plan Final (Panthera onca). Region 2, Albuquerque, U.S.A.

U.S. Fish and Wildifife Service. 2019. Draft post-delisting monitoring plan for the lesser long-nosed bat (Leptonycteris yerbabuenae). Region 2, Phoenix, Arizona, U.S.A.

U.S. Fish and Wildlife Service. 2020. Mexican wolf recovery monthly updates. October -December 2020. https://www. fws.gov/southwest/es/mexicanwolf/pdf/QuarterlyReport Fourth2020.pdf. Accessed April 1, 2021.

Valdez, E. W., ANd T. J. O'Shea. 2014. Seasonal shifts in the diet of the big brown bat (Eptesicus fuscus) Fort Collins, Colorado. The Southwestern Naturalist 59:509-514.

Van Den Bussche, R. A., J. B. Lack, D. P. Onorato, L. C. GardnerSantana, B. R. McKinney, J. D. Villalobos, M. J. Chamberlain, D. White, And E. C. Hellgren. 2009. Mitochondrial DNA phylogeography of black bears (Ursus americanus) in central and southern North America: conservation implications. Journal of Mammalogy 90:1075-1082.

Whitney, J. E., K.B Gido, T.J. Pilger, D.L. Propst, and T.F. Turner. 2015. Biotic response to consecutive wildfires in a warmwater dryland river network. Freshwater Science 34:1510-1526. Wills, W. H. 1988. Early agriculture and sedentism in the American Southwest: evidence and interpretations. Journal of World Prehistory 2:445-488. 
Wilson, J. S., AND J. P. PItTs. 2010. Illuminating the lack of consensus among descriptions of earth history data in the North American deserts: a resource for biologists. Progress in Physical Geography 34:419-441.

Yates, T. L., C. Jones, And J. A. Cook. 1996. Preservation of voucher specimens. Pp. 265-274, in Measuring and Monitoring Biological Diversity: Standard Methods for Mammals (Wilson, D., F. R. Cole, J. D. Nichols, R. Rudran, and M. S. Foster, eds.). Smithsonian Institution Press. Washington, U.S.A.

Yu, J., ANd F. S. Dobson. 2000. Seven forms of rarity in mammals. Journal of Biogeography 27:131-139.

Associated editor: Lisa and Robert Bradley

Submitted: February 6, 2021; Reviewed: March 5, 2021

Accepted: April 6, 2021; Published on line:May 28, 2021. 


\section{Appendix 1}

\begin{tabular}{|c|c|c|c|c|c|c|c|}
\hline Thomomys & & Neotoma & & Notiosorex & & Perognathus & \\
\hline Catalog \# & GenBank Accession \# & Catalog \# & GenBank Accession \# & Catalog \# & GenBank Accession \# & Catalog \# & GenBank Accession \# \\
\hline MSB140628 & MW752461 & MSB121427 & AF186799 & MSB156020 & MW156020 & ACUNHC195 & FJ514864 \\
\hline MSB141310 & MW752462 & MSB74610 & AF186800 & MSB156726 & MW156021 & ACUNHC452 & FJ514880 \\
\hline MSB269054 & MW752463 & TTU71198 & AF186806 & MSB156735 & MW156022 & ACUNHC779 & FJ514882 \\
\hline MSB269116 & MW752464 & TTU75440 & AF186809 & MSB157880 & MW156023 & LVT702 & AY926405 \\
\hline MSB270749 & MW752465 & TTU43294 & AF186815 & MSB269044 & MW156024 & LVT1050 & FJ514881 \\
\hline MSB270750 & MW752466 & TTU79129 & AF294345 & TTU142705 & AY611574 & LVT1063 & AY926389 \\
\hline MSB280649 & MW752467 & TTU101643 & AF294346 & TTU142706 & AY611573 & LVT1198 & FJ514887 \\
\hline MSB280650 & MW752468 & TTU36179 & AF298840 & MVZ148831 & AY611572 & LVT3610 & AY926383 \\
\hline MSB280908 & MW752469 & MSB60818 & KF267873 & MVZ154747 & AY611571 & MSB269161 & MW752455 \\
\hline MSB280916 & MW752470 & MSB77371 & AF186808 & MVZ154748 & AY611570 & MSB270341 & MW752456 \\
\hline MVZ146822 & EU240745 & MSB77708 & AF186811 & TTU80965 & AY611569 & MSB270584 & MW752457 \\
\hline MVZ146880 & TBU65269 & MSB82999 & EU141962 & ASNHC11431 & AY611568 & MSB278341 & MW752458 \\
\hline MVZ146927 & TBU65271 & MSB122177 & MW752445 & MVZ148830 & AY611567 & MSB284563 & MW752459 \\
\hline MVZ146961 & TBU65268 & MSB146228 & MW752446 & TTU40000 & AY611566 & MSB284623 & MW752460 \\
\hline MVZ147002 & EU240741 & MSB157277 & MW752447 & TTU142703 & AY611565 & OSU13171 & FJ514890 \\
\hline MVZ147023 & TBU65272 & MSB227112 & MW752448 & TTU80966 & AY611563 & OSU13186 & FJ514897 \\
\hline MVZ150272 & TBU64979 & MSB261214 & MW752449 & ASNHC17335 & AY611562 & OSU13188 & FJ514899 \\
\hline MVZ150298 & TBU64980 & MSB261216 & MW752450 & ASNHC10653 & AY611564 & OSU13194 & FJ514871 \\
\hline MVZ158511 & EU240739 & MSB269084 & MW752451 & UAM50408 & AY014952 & OSU13195 & FJ514869 \\
\hline MVZ158534 & TBU65270 & MSB269085 & MW752452 & & & TTU38444 & FJ514888 \\
\hline TTU127500 & AF445059 & MSB270394 & MW752453 & & & TTU75790 & FJ514865 \\
\hline TTU44656 & AF445047 & MSB270400 & MW752454 & & & TTU75817 & FJ514889 \\
\hline TTU67236 & AF445052 & MSB72986 & AF307834 & & & & \\
\hline TTU75866 & AF445055 & TTU78505 & AF308867 & & & & \\
\hline TTU76383 & AF445053 & MVZ197170 & DQ781305 & & & & \\
\hline TTU78861 & AF445061 & TTU76474 & DQ179817 & & & & \\
\hline \multirow[t]{9}{*}{ MVZ176455 } & U65291 & TTU76476 & AF376472 & & & & \\
\hline & & TTU77530 & AF186828 & & & & \\
\hline & & TTU78448 & AF186816 & & & & \\
\hline & & TTU89870 & KM488337 & & & & \\
\hline & & TTU97148 & EU141961 & & & & \\
\hline & & TTU99895 & EU141964 & & & & \\
\hline & & TTU106768 & KM488338 & & & & \\
\hline & & TTU42833 & EU286808 & & & & \\
\hline & & TK45042 & DQ179810 & & & & \\
\hline
\end{tabular}

